Flockhart, D., G. W. Mitchell, R. G. Krikun, and E. M. Bayne. 2016. Factors driving territory size and breeding success in a threatened migratory songbird, the Canada Warbler. Avian Conservation and Ecology 11(2):4. http://dx.doi.org/10.5751/ACE-00876-110204

Copyright (C) 2016 by the author(s). Published here under license by the Resilience Alliance.

Research Paper

\title{
Factors driving territory size and breeding success in a threatened migratory songbird, the Canada Warbler
}

\author{
D. T. Tyler Flockhart ${ }^{1,2}$, Greg W. Mitchell ${ }^{3}$, Richard G. Krikun ${ }^{1}$ and Erin M. Bayne ${ }^{4}$ \\ ${ }^{1}$ Lesser Slave Lake Bird Observatory, Slave Lake, Alberta, ${ }^{2}$ Department of Integrative Biology, University of Guelph, Guelph, \\ Ontario, ${ }^{3}$ Wildlife Research Division, Environment and Climate Change Canada, Ottawa, Ontario, ${ }^{4}$ Department of Biological \\ Sciences, University of Alberta
}

\begin{abstract}
Successful conservation of migratory birds demands we understand how habitat factors on the breeding grounds influences breeding success. Multiple factors are known to directly influence breeding success in territorial songbirds. For example, greater food availability and fewer predators can have direct effects on breeding success. However, many of these same habitat factors can also result in higher conspecific density that may ultimately reduce breeding success through density dependence. In this case, there is a negative indirect effect of habitat on breeding success through its effects on conspecific density and territory size. Therefore, a key uncertainty facing land managers is whether important habitat attributes directly influence breeding success or indirectly influence breeding success through territory size. We used radio-telemetry, point-counts, vegetation sampling, predator observations, and insect sampling over two years to provide data on habitat selection of a steeply declining songbird species, the Canada Warbler (Cardellina canadensis). These data were then applied in a hierarchical path modeling framework and an AIC model selection approach to determine the habitat attributes that best predict breeding success. Canada Warblers had smaller territories in areas with high shrub cover, in the presence of red squirrels (Tamiasciurus hudsonicus), at shoreline sites relative to forest-interior sites and as conspecific density increased. Breeding success was lower for birds with smaller territories, which suggests competition for limited food resources, but there was no direct evidence that food availability influenced territory size or breeding success. The negative relationship between shrub cover and territory size in our study may arise because these specific habitat conditions are spatially heterogeneous, whereby individuals pack into patches of preferred breeding habitat scattered throughout the landscape, resulting in reduced territory size and an associated reduction in resource availability per territory. Our results therefore highlight the importance of considering direct and indirect effects for Canada warblers; efforts to increase the amount of breeding habitat may ultimately result in lower breeding success if habitat availability is limited and negative density dependent effects occur.
\end{abstract}

\section{Facteurs influant sur la taille du territoire et le succès reproducteur chez un passereau migrateur menacé, la Paruline du Canada}

RÉSUMÉ. La conservation réussie d'oiseaux migrateurs passe par la compréhension de l'influence qu'ont les composantes d'habitat des aires de nidification sur le succès reproducteur. Chez les passereaux territoriaux, de nombreuses composantes sont reconnues pour influer directement sur le succès reproducteur. Par exemple, la présence d'une grande disponibilité de nourriture et d'un faible nombre de prédateurs peut avoir des effets directs sur le succès reproducteur. Toutefois, bon nombre de ces mêmes composantes d'habitat peuvent aussi entrainer une densité d'individus conspécifiques plus élevée, qui peut ultimement affaiblir le succès reproducteur en raison de la dépendance à la densité. Dans ce cas, il y a un effet indirect négatif de l'habitat sur le succès reproducteur à cause de sa répercussion sur la densité de conspécifiques et la taille des territoires. Ainsi, les gestionnaires de territoires font face à une incertitude névralgique, à savoir si les composantes d'habitat importantes influent directement sur le succès reproducteur ou si elles influent indirectement sur le succès reproducteur par la taille des territoires. Nous nous sommes servi de la radio-télémétrie, de points d'écoute, d'échantillonnage de végétation, d'observations de prédateurs et d'échantillonnage d'insectes au cours de deux années afin d'obtenir des données sur la sélection d'habitat par la Paruline du Canada (Cardellina canadensis), une espèce de passereaux dont les populations sont en diminution marquée. Ces données ont ensuite été appliquées dans un cadre de modélisation par étape hiérarchique et une approche de sélection de modèles par critère d'information d'Akaike (AIC) afin de déterminer les composantes d'habitat qui prédisent le mieux le succès reproducteur. Les Parulines du Canada avaient des territoires plus petits dans les secteurs où le couvert arbustif était élevé, en présence d'Écureuils roux (Tamiasciurus hudsonicus), dans des sites en bordure par opposition aux sites d'intérieur de forêt et à mesure que la densité d'individus conspécifiques augmentait. Le succès reproducteur était plus faible chez les oiseaux dont le territoire était plus petit, ce qui laisse penser que la compétition pour les ressources alimentaires limitées joue un rôle, mais il n'y avait pas d'indications directes que la disponibilité de nourriture agissait sur la taille des territoires ou le succès reproducteur. La relation négative entre le couvert arbustif et la taille des territoires que nous avons obtenue pourrait provenir du fait que les conditions spécifiques d'habitat sont spatialement hétérogènes, alors que les individus se concentrent dans les îlots de milieu de nidification préféré qui sont répartis dans 
l'ensemble du paysage, résultant en des territoires de plus petites tailles et une réduction consécutive de la disponibilité des ressources par territoire. Nos résultats soulignent ainsi l'importance de prendre en considération les effets directs et indirects pour la Paruline du Canada : des efforts consacrés à augmenter la quantité d'habitat de nidification pourraient ultimement aboutir à un succès reproducteur plus faible si la disponibilité d'habitat est limitée et si des effets négatifs attribuables à la dépendance à la densité se présentent.

Key Words: Cardellina canadensis; conspecific density; density dependence; food availability; habitat; path model; predator; territorial behavior

\section{INTRODUCTION}

Explaining variation in breeding success is important for identifying the causes of population declines of migratory birds (Morris 2003). Multiple factors are known to directly influence breeding success in territorial songbirds. For example, higher breeding success has been shown to correlate with greater food availability (Siikamäki 1998, Nagy and Holmes 2005), more abundant vegetation features (Martin and Roper 1988, Goodnow and Reitsma 2011), and fewer predators (Bayne and Hobson 2002, Rodenhouse et al. 2003). However, many of these same factors can also result in higher conspecific density (Van Horne 1983, Morris 2003) and both experimental (Alatalo and Lundberg 1984, Both and Visser 2000, Rodenhouse et al. 2003, Sillett et al. 2004) and observational (McKellar et al. 2014) evidence show a negative relationship between conspecific density and breeding success. The opposing directions of these effects reported in the literature presents a paradox for landscape managers: promote high quality habitat that leads to higher conspecific density that ultimately reduces breeding success. A key uncertainty then is unraveling how important vegetation conditions and resource levels are as factors directly influencing breeding success (McLoughlin and Ferguson 2000) versus the indirect effects that habitat may have on breeding success through its effects on conspecific density and territory size (Ridley et al. 2004). At the same time, understanding these causal pathways (e.g., Clotfelter et al. 2007) can guide landscape managers to make better decisions that promote key demographic parameters, such as breeding success, to accommodate species-at-risk in working landscapes (Haché et al. 2013).

Canada warblers (Cardellina canadensis) have declined steadily over the past four decades and they are listed as threated in Canada (Environment Canada 2008). There are multiple hypotheses for how habitat quality could have a direct effect on breeding success or an indirect effect on breeding success through territory size in this species (Fig. 1). For instance, higher conspecific densities could result in more aggressive interactions, e.g., singing bouts, among neighbors that reduce provisioning rate and the body condition of offspring and thereby directly reduce breeding success (Fig. 1). An indirect effect would predict smaller territory sizes in areas with higher conspecific density that reduce the probability of breeding success (Both and Visser 2000). These same patterns could emerge in the presence of predators whereby predators have direct negative effects on breeding success (Bayne and Hobson 2002) or indirectly reduce breeding success by altering adult behavior and territory size (Zanette et al. 2011). Canada Warblers occupy forest with dense shrubs (Hallworth et al. 2008a) and feed on invertebrates (Reitsma et al. 2010), which predicts a direct positive relationship between shrub cover and insect abundance with breeding success (Goodnow and Reitsma 2011; Fig. 1). Alternatively, there may be an indirect effect between shrub cover and insect abundance with breeding success if these habitat resources are locally sparse and force warblers to increase the size of their territory to encounter enough of these resources for successful breeding (Fig. 1).

Fig. 1. Global path model depicting direct and indirect relationships between variables hypothesized to effect territory size and breeding success for Canada Warblers (Cardellina canadensis) in western Canada. Solid black arrows represent hypothesized positive effects, grey arrows represent hypothesized negative effects, and hatched black arrows represent paths for which the direction of effect is unknown, i.e., a positive or negative effect could be reasonably expected.

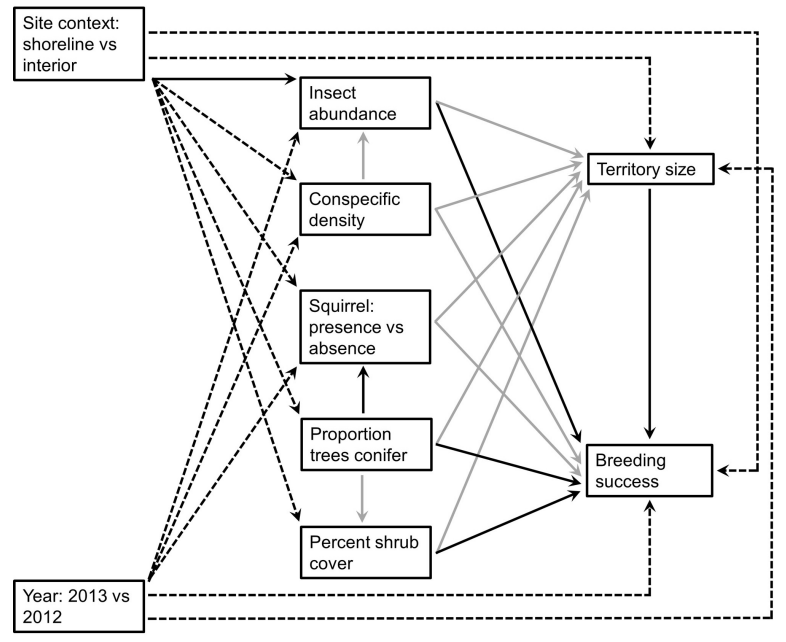

In this study, we measured territory size, vegetation attributes of territories and the landscapes in which they were situated, insect availability, the presence of predators, and conspecific density of Canada Warblers near the northern edge of their breeding range in central Alberta, Canada, to determine the interplay between predation risk, food abundance, competition, and density as factors influencing breeding success (Fig. 1). Our objectives were to provide data on the factors influencing habitat quality in this federally listed threatened species (Environment Canada 2008, Environment Canada 2016) and identify factors limiting breeding success on the breeding grounds. Our study should assist land managers with understanding the trade-off between habitat quality, warbler population density and population growth rate when designing optimal management plans. 


\section{METHODS}

\section{Study area}

The study was conducted from 31 May to 15 August 2012 and 4 June to 15 August 2013 in Lesser Slave Lake Provincial Park (7700

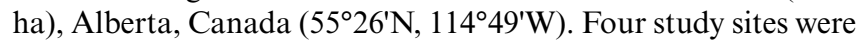
selected based on detections of Canada Warblers during randomized point counts that were conducted across the provincial park in 2010; sites were separated by approximately 2 $\mathrm{km}$ and centered on areas where Canada Warblers were detected in high densities. Two sites were adjacent to Lesser Slave Lake (580-620 m elevation) and two were at the higher elevation forest interior (hereafter referred to as site context; shoreline versus interior). One interior forest site bordered a major creek complex and the second interior forest site was located along the side of Marten Mountain. The Marten Mountain site was at a higher elevation with a steeper gradient $(760-850 \mathrm{~m})$ compared with the second interior forest site $(625-650 \mathrm{~m})$. Each site was approximately 60 ha in size with mature ( $>80$ years) or old-growth ( $>130$ years) mixed boreal forest dominated by trembling aspen (Populus tremuloides), balsam poplar (P. balsamifera), white spruce (Picea glauca), and white birch (Betula papyrifera). The shrub understory $(<8 \mathrm{~cm} \mathrm{dbh})$ was dominated by tree saplings, willow (Salix spp.), green alder (Alnus viridis), beaked hazelnut (Corylus cornuta), red-oiser dogwood (Cornus stolonifera), saskatoon (Amelanchier alnifolia), prickly rose (Rosa acicularis), low bush-cranberry (Viburnum edule), choke cherry (Prunus virginiana), and bracted honeysuckle (Lonicera involucrate). The ground cover consisted of forbs, mosses, ferns, and grasses. Sites were well drained with little to no standing water and contained small drainage streams.

\section{Territory size and breeding success}

We used radio-telemetry to estimate the territory size of male Canada Warblers. Individuals were captured using targeted mistnetting with a conspecific audio playback, banded with two plastic color bands and a numbered aluminum leg band, and fitted with a 0.31 g radio-transmitter (Model LB-2X; Holohil Systems Ltd., Carp, Ontario, Canada). Transmitters were glued to a small piece of chiffon using a cyanoacrylate adhesive to increase surface area, then attached to birds using the same adhesive over the synsacrum. Prior to radio placement feathers were trimmed to 1-2 mm stubs and we ensured the total weight of all attachments was approximately $0.51 \mathrm{~g}$, which is $5 \%$ of the mean body weight of breeding adult male Canada Warblers from our study area $(\mu$ $=10.5 \mathrm{~g}, \mathrm{SD}=0.5 \mathrm{~g}, n=166$ ).

Territory tracking was divided into two rounds during the nesting season to accommodate the short battery life of the transmitters ( 21 days) and the short duration of the breeding season of this warbler (Flockhart 2007). The first tracking round (11 - 20 June) encompassed the incubation period and the second tracking round ( 21 - 30 June) included the nestling period (Flockhart 2010). Defended area may change depending on the period of the breeding season (Barg et al. 2005) but we did not find differences in estimated territory size between first (mean $=0.43 \mathrm{ha}, \mathrm{SD}=$ $0.23, \mathrm{n}=15$ ) and second (mean $=0.51 \mathrm{ha}, \mathrm{SD}=0.27, \mathrm{n}=15$ ) rounds of tracking (Welch's t-test, $\mathrm{t}=-0.859, \mathrm{df}=27, \mathrm{p}=0.4$ ). We targeted four adjacent territorial males within each site in 2012 and in 2013. We tracked eight males each round, focusing on four males in two separate study sites. Each round began with two to three days of target banding. After a 24 hour adjustment period, we tracked birds daily from 0500 until 1300 for the remainder of the round. Tracking consisted of honing onto the position of an individual using H-Yagi antenna (Telonics, Inc., Mesa, Arizona, USA) and R-1000 radio-transceiver (Communication Specialists, Inc., Orange, California, USA) and following the strength of the signal to the bird's location. We approached the position from multiple angles to ensure the location and attempted to obtain a visual confirmation of the bird's location. At times, location points were estimated based on the strength of the receiver signal (estimated accuracy $\pm 5 \mathrm{~m}$ ). Each location point was recorded using a GPS unit (Garmin 76CSx), ensuring the accuracy was below $\pm 5 \mathrm{~m}$. We attempted to collect a minimum of 40 location points for each individual and maintained a minimum of 10 minutes between observations to minimize the interdependence of the location points (Barg et al. 2005, Hallworth et al. 2008b).

All statistical modeling was done in R 3.1.2 (R Core Team 2014). We calculated $50-95 \%$ kernel density estimates (KDE) using all recorded locations in the Adehabitat package (Calenge 2006), using least-squares cross-validation as the smoothing parameter. We found that one bird had a territory size that was consistently much larger than all other birds across all KDE contours (e.g., $\min 50 \% \mathrm{KDE}=0.12$ ha, median $50 \% \mathrm{KDE}=0.50$ ha, outlying value $=2.38 \mathrm{ha}$, second largest $50 \% \mathrm{KDE}$ value $=0.97 \mathrm{ha}$ ), and was subsequently removed from all analyses. We measured breeding success of each radio-tagged male by making provisioning observations. Canada Warbler parents are conspicuous while provisioning because fledglings depart the nest before they can fly and remain in dense shrub foliage for more than a week. Males observed carrying food during tracking bouts or during a specific 1-hour observation session after tracking had concluded, were deemed successful breeders.

\section{Vegetation}

Vegetation sampling was conducted from 23 July - 15 August and the sample in each territory was taken at the peak of the density curve of both the latitude and longitude derived from KDE indicated above. Shrubs are thought to be a key habitat attribute for Canada Warbler (Hallworth et al. 2008b, Goodnow and Reitsma 2011, Alberta Environment and Sustainable Resource Development and Alberta Conservation Association 2014, Environment Canada 2016) so we initially examined three measures of shrubs in each territory: percent shrub cover, shrub density, and percent shrub cover that was conifer. To estimate shrub density, all shrubs ( $>50 \mathrm{~cm}$ height, $<8 \mathrm{~cm} \mathrm{dbh}$ ) were counted within a $5-\mathrm{m}$ radius of the plot centre. An estimation of the percent shrub cover $(0-50 \mathrm{~cm}$ above ground $)$ and the percent shrub cover that was conifer was recorded in four quadrants of the 5-m radius circle (Hallworth et al. 2008b). The percent shrub cover and percent shrub cover that was conifer was estimated as the mean of the four quadrants (Table 1). Finally, we identified and counted all canopy trees $(>8 \mathrm{~cm} \mathrm{dbh})$ in an $11.3 \mathrm{~m}$ radius circle around each point. To calculate the percent of the canopy trees that were conifers (which is also a confounded habitat attribute for red squirrels (Tamiasciurus hudsonicus), see Predators below) we divided the number of conifer trees by the total number of trees (Grinde and Niemi 2016; Fig. 1). 
Table 1. Mean (standard deviation in parentheses) values of breeding territory attributes of Canada Warblers (Cardellina canadensis) in 2012 and 2013 at Slave Lake, Alberta. All variables were measured for each individual warbler except insect abundance and conspecific density that were measured at the site level.

\begin{tabular}{lcc}
\hline \hline Variable & 2012 & 2013 \\
\hline $\begin{array}{l}\text { Measured at the territory level (sample } \\
\text { size) }\end{array}$ & 16 & 14 \\
Territory size & & \\
$50 \%$ Kernel Density Estimate (ha) & $0.42(0.20)$ & $0.52(0.30)$ \\
Vegetation & $49.3(13.1)$ & $53.1(28.1)$ \\
Percent shrub cover & $6.5(14.7)$ & $5.6(8.3)$ \\
Percent of canopy trees that were conifers & 0.5 & 0.14 \\
Predators (present $/ n$ ) & 0.63 & 0.64 \\
Breeding Success (successful/ $n$ ) & 4 & 4 \\
Measured at the site-level (sample size) & & \\
Insect Abundance & $167(94)$ & $41(12)$ \\
Malaise - Abundance & & \\
Conspecific Density & $1.00(0.49)$ & $0.52(0.20)$ \\
Male warbler density (warblers/3.14ha)
\end{tabular}

\section{Insect abundance}

One insect sampling location was established at each of the four sites. Each site was sampled with a Townes Style Malaise trap $(176 \mathrm{~cm} \times 165 \mathrm{~cm} \times 180 \mathrm{~cm})$ for a 24-hour period during three points in the breeding season: territory establishment $(25-29$ May 2012; 24 - 28 May 2013), nest establishment and nesting (18 - 30 June 2012; 14 - 17 June 2013), and provisioning of fledglings (5 - 7 July 2012; 1 - 2 July 2013). All insects captured were transferred to containers with $70 \%$ isopropyl rubbing alcohol and counted. We used the mean insect count over the three time periods for each study site in the analysis (Table 1). Although the diet of Canada Warbler is poorly known, adults forage mainly on flying insects, which are sampled by Malaise traps (Reitsma et al. 2010).

\section{Conspecific density}

Point counts were conducted to estimate the abundance of Canada warblers in each site. Between 9 and 11 points were sampled at each site and points were approximately $200 \mathrm{~m}$ apart. Each point was surveyed twice in 2012 from 31 May to 8 June but only once from 4 June to 9 June in 2013. We therefore only considered the first point count session in 2012 to match the point count effort conducted in 2013. Point counts consisted of a 5minute silent listening period followed by a call playback sequence containing a 20-second Canada Warbler territorial song followed by a 1 -minute silent listening period, repeated 3 times. For each point we counted the number of males detected within $100 \mathrm{~m}$ of the observer and then used the mean number of individuals counted per point (warblers/3.14 ha) to estimate the conspecific density of Canada Warblers at each site (Table 1).

\section{Predators}

We recorded the location of all red squirrels encountered during field activities to estimate predator presence. For each territory, we considered a squirrel to be present in the territory of the warbler if at any point during the field season a squirrel was heard or seen on the territory (Table 1). Observations were made during point counts and radio-tracking bouts during the breeding season so the presence of a squirrel implied the squirrel was a potential predator of the warbler's nest based on estimates of home range size of squirrels (Gurnell 1984) being larger than those of Canada Warblers (Hallworth et al. 2008a).

\section{Path model}

To examine the effects of insect abundance, conspecific density, squirrel presence/absence, percent conifer tree cover, shrub cover, site context, and year on territory size and breeding success we used a multilevel path modeling framework (Shipley 2009). We fit the model in two stages to facilitate model fit and evaluation. First, we fit a path model examining the effect of site context and year on insect abundance, conspecific density, squirrel presence/ absence, as well as the effect of site context on percent conifer tree cover and shrub cover, the effect of conspecific density on insect abundance, and the effects of percent conifer tress on squirrel presence/absence and percent shrub cover (Fig. 1). Within this path model, we fit submodels of insect abundance using generalized linear models with a quasi-Poisson family (stats package; R Core Team 2014) to account for overdispersion, submodels of conspecific density using linear models (stats package), and submodels of squirrel presence/absence using generalized linear mixed models (family = binomial; lme4 package; Bates et al. 2014), with a random effect for study site to account for spatial autocorrelation. Last, we fit submodels of percent conifer trees and percent shrub cover with linear mixed effects models, where we also included a random effect for study site (lme4 package). For these and all subsequent models we evaluated collinearity among predictor variables using correlation coefficients and variance inflation factors (VIFs; car package; Fox and Weisberg 2011), as well as examined the effect of variable removal on parameter estimates for correlated predictor variables. For this subset of models we did not find any evidence for strong collinearity (i.e., all $\mathrm{r}<0.49$ or VIF $<1.4$ ).

In the second stage of our path modeling exercise, we took the most parsimonious path model from the first stage (see below) and added paths for the direct effects of insect abundance, conspecific density, squirrel presence/absence, percent conifer trees, shrub cover, site context, and year on territory size and breeding success, as well as a path for the direct effect of territory size on breeding success (Fig. 1). We examined submodels for territory size and breeding success using linear mixed effects models and generalized linear mixed effects models (family = binomial; lme4 package), respectively, where a random effect for study site was included to account for spatial autocorrelation. When considering the submodel for territory size, we found moderate collinearity between year and insect abundance (VIF year $=5.4$, VIF insect abundance $=4.2, \mathrm{r}=0.68$ ), however, removing the year term from the model had little effect on parameter estimates and was therefore retained. With respect to our submodel for breeding success, we also found collinearity between year and insect abundance (VIF year $=11.1$, VIF insect abundance $=8.9, r=0.65$ ), but for this model, removal of the year term resulted in a large effect on the parameter estimate for insect abundance, therefore, we dropped the path between year and breeding success prior to model selection. 
To derive the most parsimonious path model for both modeling stages we used an AIC model selection procedure (Shipley 2013). We did not use a small sample correction, because it is unclear how sample size is defined when the model is hierarchical, e.g., where the sample size for the path between site context and insect abundance $(n=8)$ varies from the sample size for the path between site context and percent shrub cover $(n=30)$ within the same path model. Terms were removed from the path model if their deletion did not increase the AIC statistic by at least two units. For the first stage of modeling, we removed terms from the models of insect abundance first, followed by conspecific density, squirrel presence/absence, the percent shrub cover that were conifer trees, and then percent shrub cover. For each of these submodels, order of deletion was determined by examining which model terms had the least support in terms of AICc statistics when examining all model subsets fit using maximum likelihood (MuMIn package; Barton 2015). We did not conduct model averaging because the top models were all nested versions of the preceding models (Arnold 2010). Parameter estimates for continuous variables presented in the results are for standardized data. All mean values are reported with \pm 1 standard deviation and all median values are presented with ranges in parentheses. Further details of the path modeling is provided in the Appendix 1.

\section{RESULTS}

Thirty male Canada Warblers were tracked over study (Table 1). Of these, 16 were in shoreline sites and 14 were in interior sites (Table A1.1). Twenty-eight individuals had over 40 location points recorded over the two years (mean number of observations over all individuals $=47.5, \mathrm{SD}=8.2$ ) but the $50 \% \mathrm{KDE}$ of individuals that had $<40$ observations was not significantly different compared with individuals that had $>40$ observations $(t=-1.75$, $d f=27, p=0.09$; Table A1.1). The mean $50 \% \mathrm{KDE}$ was 0.468 ha $(\mathrm{SD}=0.251 \mathrm{ha})$. Red squirrels were detected on 10 territories of Canada Warblers (Proportion $=0.33,95 \%$ CI: $0.19-0.52$; Table 1).

Insect abundance was higher in 2012 (median $=161(58-287))$ compared to $2013($ median $=42(26-55)$; intercept $=5.4, \mathrm{SE}=$ $0.3, \beta=-1.4, \mathrm{SE}=0.4$; Table A1.2) and insects were more abundant at interior sites $($ median $=161(41-287))$ relative to shoreline sites $($ median $=50(26-160) ; \beta=-0.6, \mathrm{SE}=0.3$; Table A1.2). There was no evidence for an effect of either year or site context on conspecific density, squirrel presence/absence, percent conifer trees or shrub cover, an effect of percent conifer trees on squirrel presence/absence, an effect of percent conifer trees on shrub cover, or an effect of conspecific density on insect abundance (Table A1.2).

With respect to territory size, there was evidence for effects of percent shrub cover, squirrel presence/absence, site context, and conspecific density (Fig. 2, Table A1.3). Specifically, territory size decreased as percent shrub cover increased (intercept $=0.7, \mathrm{SE}=$ $0.3, \beta=-0.5, \mathrm{SE}=0.2$; Fig. 3, Table A1.3). Territory sizes were also smaller in areas where squirrels were present (partial residual mean $=-0.10 \pm 0.15)$ relative to areas where they were absent (partial residual mean $=0.05 \pm 0.20 ; \beta=-0.7, \mathrm{SE}=0.3$; Fig. 4 , Table A1.3). Together, both of these variables accounted for the majority of explained variation in the submodel for territory size (marginal adjusted $\mathrm{R}^{2}=42 \%$, Figs. 2 and 3 ). Territory sizes tended to be slightly smaller at shoreline sites (partial residual mean
Fig. 2. Final path model from AIC model selection procedure depicting variables affecting territory size and breeding success for Canada Warblers (Cardellina canadensis) in Western Canada. Arrows are scaled in size relative to the increase in the AIC statistic when the parameter in question is removed from the top model. Effect sizes are based on standardized continuous covariates. Negative effects are represented by the grey arrows as well as the negative sign associated with each parameter estimate.

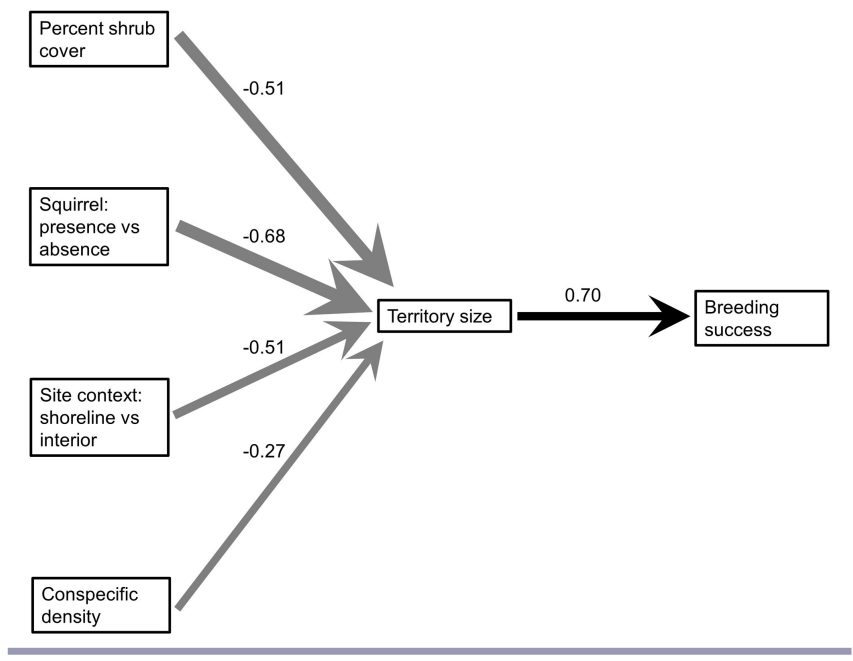

Fig. 3. Partial residual plot illustrating the relationship between percent shrub cover and territory size. The grey area represents the $95 \%$ confidence interval for the fitted values. The bracket on the top, from left to right, illustrates the minimum, median, and maximum percent shrub cover measured at the center of each territory, respectively. The bracket on the right, from top to bottom, illustrates the maximum, median, and minimum measurements for territory size (ha; $50 \% \mathrm{KDE}$ contour), respectively.

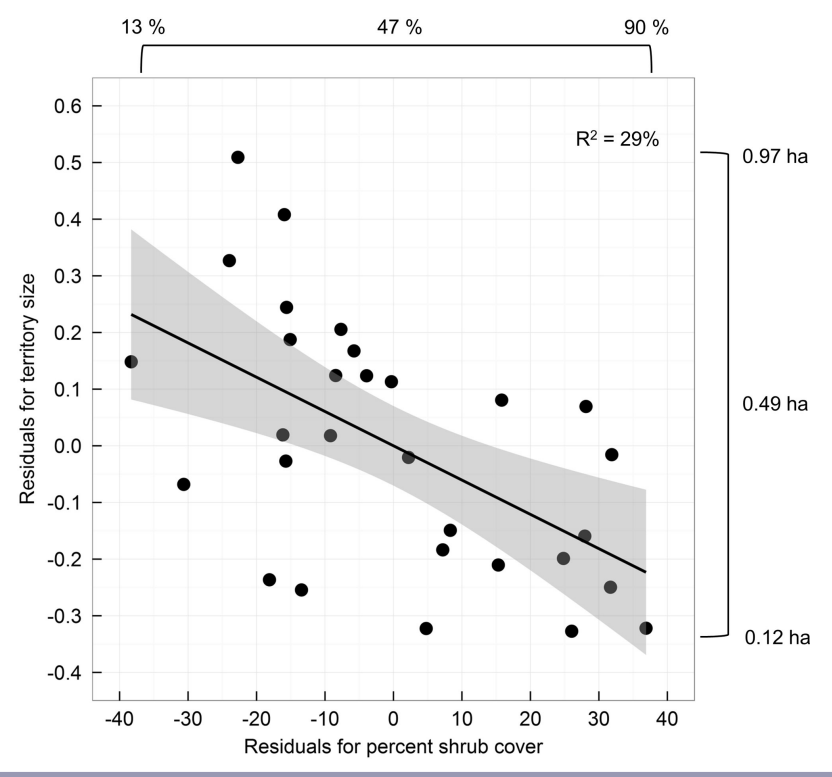


$=-0.04 \pm 0.22)$ relative to interior sites (partial residual mean $=$ $0.04 \pm 0.14 ; \beta=0.3, \mathrm{SE}=0.3$ ), and territory sizes were more variable at shoreline sites (Fig. A1.1). Last, there was a relatively weak and negative correlation between conspecific density and territory size $(\beta=-0.3, \mathrm{SE}=0.2 ; \mathrm{Fig}$. A1 .2). There was no evidence for an effect of insect abundance on territory size (Table A1.3), and thus, no evidence for an indirect effect of year or site context on territory size through insect abundance. There was no evidence for an effect of percent conifer trees on territory size (Table A1.3).

Fig. 4. Partial residual boxplot illustrating the relationship between squirrel presence/absence and territory size. The solid black horizontal line in each box represents the median and the square in each box represents the mean. The area above and below the horizontal line represents the 50th to the 75th and the 25 th to the 50 th percentiles, respectively. The vertical lines or whiskers extend to the highest and lowest values contained within 1.5 times the interquartile range of the data. The bracket on the right, from top to bottom, illustrates the maximum, median, and minimum measurements for territory size (ha; $50 \%$ KDE contour), respectively.

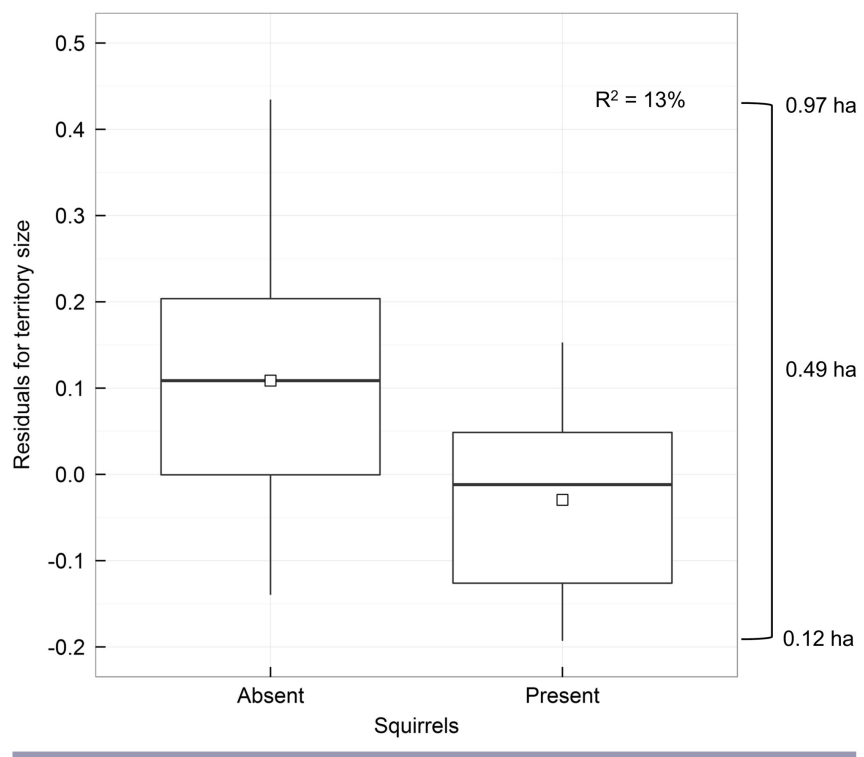

There was evidence for a direct effect of territory size on breeding success, where breeding success increased as territory size increased (intercept $=0.6, \mathrm{SE}=0.4, \beta=-0.7, \mathrm{SE}=0.4$; Fig. 5, Table A1.3). Therefore, given the direct effects of shrub cover, squirrel presence/absence, conspecific density, and site context on territory size, there was evidence for indirect negative effects of these variables on breeding success (Fig. 2). Specifically, breeding success declined with conspecific density and was lower when squirrels were present in territories with dense shrub cover near shorelines (Fig. 2). There was no evidence for a direct effect of conspecific density, squirrel presence/absence, percent conifer trees, or percent shrub cover on breeding success (Table A1.3). We also did not find any evidence for an effect of insect abundance on territory size (Table A1.3), and thus no evidence for an indirect effect of year or site context through insect abundance. The marginal $\mathrm{R}^{2}$ value for our model of breeding success was $13 \%$.
Fig. 5. Plot illustrating the relationship between territory size and breeding success. The black trend line represents a smoothed loess line fit to the predicted values from the logistic regression of breeding success on territory size and the grey area represents the $95 \%$ confidence interval for the fitted line. Solid black circles represent breeding successes (value $=1$ ) and failures (value $=0$ ) with respect to associated territory sizes. Solid grey circles and error bars represent the proportion of successful nests and associated standard errors calculated from the raw data for territory sizes (ha; $50 \% \mathrm{KDE}$ contour) binned in 0.25 ha increments.

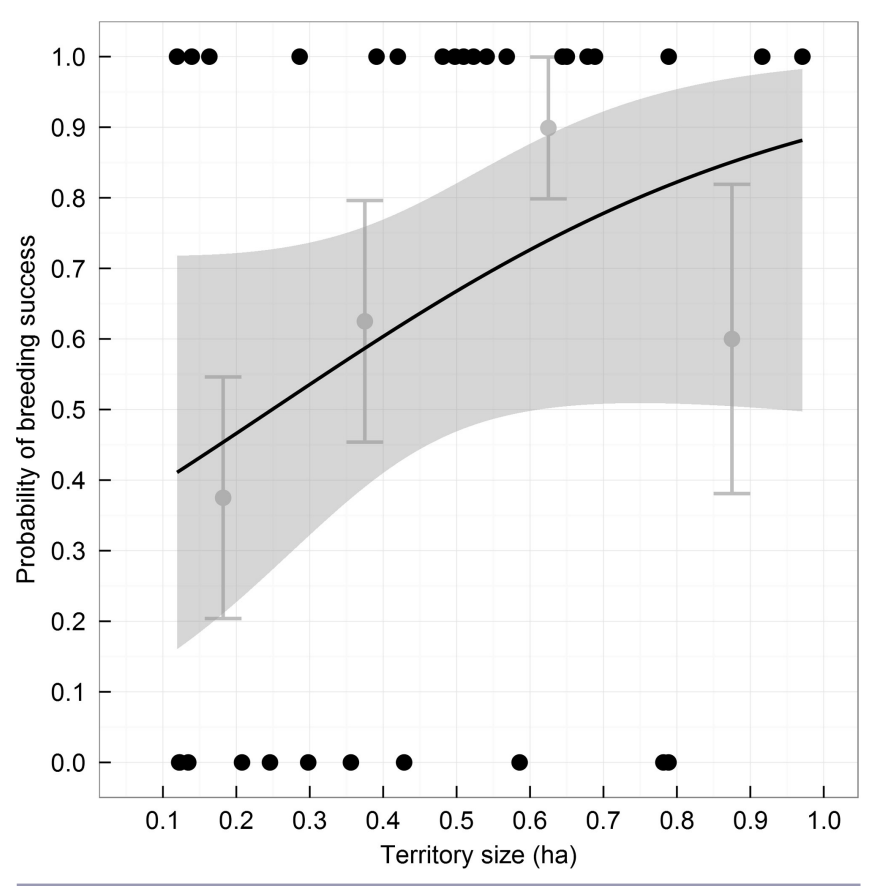

\section{DISCUSSION}

Our results suggest that breeding success of Canada Warblers in central Alberta was influenced by territory size, with larger territories having higher breeding success. Territory size was smaller in areas with dense shrubs, higher warbler density, in areas that were occupied by red squirrels, and near shorelines. The weak evidence that conspecific density reduced territory size implies density dependence on the breeding grounds but this relationship was not directly driven by food availability because the abundance of insects did not influence territory size or breeding success. These findings are important for conservation planning for this at-risk species because they imply a limit to the number of territories that can successfully fledge young in the landscape, which in turn has implications for population recovery and the identification of critical habitat.

Larger territory sizes often confer greater access to resources and lead to higher breeding success (Nagy and Holmes 2005). Although Canada warblers showed higher breeding success with larger territory size, there was no evidence that food availability influenced territory size or breeding success. There are two possible reasons for this outcome: food is limiting but we were 
unable to detect it or food is not limiting. Food may be a limiting factor but we may have used the wrong sampling methodology to estimate food availability. The diet of Canada Warblers during the breeding season is poorly known but they are considered insect generalists that feed both by hawking flying insects and gleaning vegetation (Reitsma et al. 2010). Although the abundance of flying insects captured in Malaise traps served as a convenient proxy for food availability, it may not have adequately captured food availability for two reasons. First, we sampled insect availability at the site-level, which may obscure variation in food availability among territories and its subsequent effect on territory size or breeding success. Insect abundance may be important to territory size or breeding success, but our conclusions are relative to the scale at which each predictor was measured. Second, knowing which types of insects are provisioned to offspring would establish the most appropriate sampling protocol for robustly estimating food availability in a territory (e.g., Trevelline et al. 2016).

Alternatively, food may not be a limiting factor and hence our measure of territory size captured something that we did not directly measure. For example, more and better options for nesting sites or the attraction of a higher quality mate are plausible options. On the other hand, there was a negative relationship between territory size and percent shrub cover, a habitat resource that seems to be selected by Canada Warblers (Hallworth et al. 2008b, Goodnow and Reitsma 2011, Environment Canada 2016). In this case, territory size may depend on local habitat quality (Morris 2003) that arises through conspecific competition and territory defence (Stamps 1990, Ridley et al. 2004, Adams 2001). Canada warblers had smaller territories as percent shrub cover increased, possibly because birds are packing into these areas and food is not a limited resource in these territories (Venier et al. 2012). Given that dense understory shrub habitat it is a strong indicator of Canada Warbler occupancy (Hallworth et al. 2008b) and breeding success (Goodnow and Reitsma 2011), we propose that local Canada Warbler density is highest in dense shrub understory habitat in old-growth boreal forest where it may be limited to small canopy openings caused from succession, insects, blow downs, or forestry-related activities. Because these specific habitat conditions are spatially heterogeneous, it provides one proximate explanation why Canada Warblers are considered to be semicolonial breeders (Reitsma et al. 2010). Overall, Canada Warblers that maintain larger territories likely have higher breeding success because they have greater access to resources, have higher quality mates, or are higher quality themselves.

Making informed conservation decisions requires understanding the causal pathways of how habitat, territory size, and breeding success interact (Morris 2003). Hierarchical path modeling and model selection provides a suitable method to concurrently assess both direct and indirect effects of habitat attributes on breeding success (Shipley 2013). For example, had we looked only at direct relationships we would not have detected an indirect negative effect of shrub cover on breeding success, which as discussed above, may result from a negative density dependent effect resulting from birds packing into patchily distributed habitat. However, to be clear, we are not advocating that managers reduce shrub density on the breeding grounds to increase breeding success. Instead, we are suggesting that creating additional shrub habitat in the landscape may limit negative density dependent effects and that additional research is needed to fully understand how and if competition for specific habitat features is affecting reproductive success. Our results should also caution that without a complete understanding of the direct and indirect mechanisms affecting reproductive success, even well-intentioned management actions may not have the desired effect to conserve at-risk species.

Population density is often used to indicate habitat quality but in the presence of density dependence this assumption must be considered cautiously (Van Horne 1983, Morris 2003). In suitable habitat, both observations and modeling indicate Canada Warblers show heterogeneous occupancy (Grinde and Niemi 2016) and population density (Hallworth et al. 2008a, Reitsma et al. 2010, Chandler and Hepinstall-Cymerman 2016). In northern Alberta, at least under the range of warbler densities observed, there was evidence that increasing conspecific density reduced territory size which indirectly reduced breeding success. However, the relative effect of conspecific density on territory size was less compared with the relative effect of habitat features such as shrubs on territory size. Given our inability to detect food as a limiting factor on territory size, and in the absence of information on population density, it appears that assessing habitat quality from measurements of population density is a suitable proxy to identifying high quality habitat for Canada Warblers at a landscape-scale. Ideally, managers would collect data to determine local Canada Warbler population densities because it negatively influences fitness through the indirect effects of crowding on breeding success.

Many life history attributes of Canada Warblers are poorly described so our metrics of food availability, predators, and breeding success should be treated with some caution. Nest predators of Canada Warbler have not been described owing to the difficulty of locating and monitoring a large number of nests. We assumed that red squirrels, which are abundant in our study area and are one of the primary nest predators in this portion of the boreal forest (Bayne and Hobson 2002), were a realistic measurement for predator density and hence risk. Perceived predation risk has been shown to influence female behavior and reduce breeding success in song sparrows, Melospiza melodia (Zanette et al. 2011). For male Canada Warblers, response to perceived predation risk may be manifest in behavioral changes such as increased provisioning rates (Moks et al. 2016) or supressed singing activity (Fontaine and Martin 2006) that reduce territory vigilance and may lead to smaller territory size. Taken together, our data suggest that predators may be indirectly affecting breeding success and this may occur from changes in adult behavior that increase provisioning or nest attentiveness in the presence of squirrels (Lima 2009).

Previous research on Canada Warbler on the breeding grounds has found limited evidence that nesting habitat limits population growth to explain the 40-year population decline of this species (Reitsma et al. 2010, Environment Canada 2016). However, our evidence of habitat-mediated effects on breeding success for Canada Warblers, coupled with data suggesting survival away from the breeding grounds may be declining over time (S. Wilson, personal communication), highlights the need for understanding year-round population dynamics in this species. For example, competition among conspecifics for suitable breeding habitat could manifest as higher survival in other portions of the annual 
cycle via compensatory density dependence (Sutherland 1996). Given the emerging information on demography at either end of the annual cycle now requires understanding how individuals are connected between breeding and nonbreeding seasons because it influences both population dynamics (Webster et al. 2002) and informs conservation planning (Martin et al. 2007). Ultimately, integrating demography and migratory connectivity across the annual cycle can identify which threats contribute the most to population viability (Flockhart et al. 2015) to prioritize costeffective actions to mitigate population declines in threatened migratory songbirds (Sheehy et al. 2010).

Responses to this article can be read online at: http://www.ace-eco.org/issues/responses.php/876

\section{Acknowledgments:}

D. Drury, A. Nerbas, R. O'Neill, S. Sandford, and especially N. Krikun assisted with data collection. S. Mackenzie and D. Stepnisky provided feedback during project planning. Logistical support and access to field sites was provided by Alberta Parks. Funding was provided by Alberta Parks 2012 Research Grant, Alberta Conservation Association (GECF 030-00-90-128), Alberta Summer Temporary Employment Program (SWM245708), Service Canada (FMA-011545399, FMA-011971488), West Fraser Mills Ltd. Slave Lake, and a Habitat Stewardship Grant for Species at Risk (2013HSP6609). We thank D. Robinson, D. Morris, and R. Norris for valuable comments that improved the manuscript.

\section{LITERATURE CITED}

Adams, E. S. 2001. Approaches to the study of territory size and shape. Annual Review in Ecology and Systematics 32:277-303. http://dx.doi.org/10.1146/annurev.ecolsys.32.081501.114034

Alatalo, R. V., and A. Lundberg. 1984. Density-dependence in breeding success of the Pied Flycatcher (Ficedula hypoleuca). Journal of Animal Ecology 53:969-977. http://dx.doi. org/10.2307/4671

Alberta Environment and Sustainable Resource Development and Alberta Conservation Association. 2014. Status of Canada Warbler (Cardellina canadensis) in Alberta. Alberta Status Report No. 70. Alberta Environment and Sustainable Resource Development, Edmonton, Alberta, Canada.

Arnold, T. W. 2010. Uninformative parameters and model selection using Akaike's Information Criterion. Journal of Wildlife Management 74:1175-1178. http://dx.doi.org/10.2193/2009-367

Barg, J. J., J. Jones, and R. J. Robertson. 2005. Descripting breeding territories of migratory passerines: suggestions for sampling, choice of estimator, and delineation of core areas. Journal of Animal Ecology 74:139-149. http://dx.doi.org/10.1111/ j.1365-2656.2004.00906.x

Barton, K. 2015. Multi-model inference. R package version 1.15.1. The R Project for Statistical Computing, Vienna, Austria.
Bates, D., M. Maechler, B. Bolker, and S. Walker. 2014. Ime4: linear mixed-effects models using Eigen and S4. R package version 1.1-6. The R Project for Statistical Computing, Vienna, Austria.

Bayne, E. M., and K. A. Hobson. 2002. Effects of red squirrel (Tamiasciurus hudsonicus) removal on survival of artificial songbird nests in boreal forest fragments. American Midland Naturalist 147:72-79. http://dx.doi.org/10.1674/0003-0031(2002) 147[0072:EORSTH]2.0.CO;2

Both, C., and M. E. Visser. 2000. Breeding territory size affects fitness: an experimental study on competition at the individual level. Journal of Animal Ecology 69:1021-1030. http://dx.doi. org/10.1111/j.1365-2656.2000.00458.x

Calenge, C. 2006. The package adehabitat for the R software: a tool for the analysis of space and habitat use by animals. Ecological Modelling 197:516-519. http://dx.doi.org/10.1016/j. ecolmodel.2006.03.017

Chandler, R., and J. Hepinstall-Cymerman. 2016. Estimating spatial scales of landscape effects on abundance. Landscape Ecology 31:1383-1394. http://dx.doi.org/10.1007/s10980-016-0380$\mathrm{Z}$

Clotfelter, E. D., A. B. Pedersen, J. A. Cranford, N. Ram, E. A. Snajdr, V. Nolan Jr., and E. D. Ketterson. 2007. Acorn mast drives long-term dynamics of rodent and songbird populations. Oecologia 154:493-503. http://dx.doi.org/10.1007/s00442-007-0859$\mathrm{z}$

Environment Canada. 2008. COSEWIC assessment and status report on the Canada Warbler, Wilsonia canadensis, in Canada. Committee on the Status of Endangered Wildlife in Canada, Gatineau Québec, Canada.

Environment Canada. 2016. Recovery strategy for the Canada Warbler (Cardellina canadensis) in Canada. Species at Risk Act Recovery Strategy Series. Environment Canada, Ottawa, Ontario, Canada.

Flockhart, D. T. T. 2007. Migration timing of Canada Warblers near the northern edge of their breeding range. Wilson Journal of Ornithology 119:712-716. http://dx.doi.org/10.1676/06-111.1

Flockhart, D. T. T. 2010. Timing of events on the breeding grounds for five species of sympatric warblers. Journal of Field Ornithology 81:373-382. http://dx.doi.org/10.1111/j.1557-9263.2010.00293. $\mathrm{x}$

Flockhart, D. T. T., J.-B. Pichancourt, D. R. Norris, and T. G. Martin. 2015. Unravelling the annual cycle in a migratory animal: breeding-season habitat loss drives population declines of monarch butterflies. Journal of Animal Ecology 84:155-165. http://dx.doi.org/10.1111/1365-2656.12253

Fontaine, J. J., and T. E. Martin. 2006. Habitat selection responses of parents to offspring predation risk: an experimental test. American Naturalist 168:811-818. http://dx.doi.org/10.1086/508297

Fox, J., and S. Weisberg. 2011. An $R$ companion to applied regression. Second edition. Sage, Thousand Oaks, California, USA. [online] URL: http://socserv.socsci.mcmaster.ca/jfox/ Books/Companion/ 
Goodnow, M. L. and L. R. Reitsma. 2011. Nest-site selection in the Canada Warbler (Wilsonia canadensis) in central New Hampshire. Canadian Journal of Zoology 89:1172-1177. http:// dx.doi.org/10.1139/z11-094

Grinde, A. R. and G. J. Niemi. 2016. Influence of landscape, habitat, and species co-occurrence on occupancy dynamics of Canada Warblers. Condor 118:513-531. http://dx.doi.org/10.1650/ CONDOR-15-168.1

Gurnell, J. 1984. Home range, territoriality, caching behaviour and food supply of the red squirrel (Tamiasciurus hudsonicus fremonti) in a subalpine lodgepole pine forest. Animal Behaviour 32:1119-1131. http://dx.doi.org/10.1016/S0003-3472(84)80228-6

Haché, S., M.-A. Villard, and E. M. Bayne. 2013. Experimental evidence for an ideal free distribution in a breeding population of a territorial songbird. Ecology 94:861-869. http://dx.doi. org/10.1890/12-1025.1

Hallworth, M., P. M. Benham, J. D. Lambert, and L. Reitsma. 2008a. Canada Warbler (Wilsonia canadensis) breeding ecology in young forest stands compared to a red maple (Acer rubrum) swamp. Forest Ecology and Management 255:1353-1358. http:// dx.doi.org/10.1016/j.foreco.2007.10.045

Hallworth, M., A. Ueland, E. Anderson, J. D. Lambert, and L. Reitsma. 2008b. Habitat selection and site fidelity of Canada Warblers (Wilsonia canadensis) in central New Hampshire. Auk 125:880-888. http://dx.doi.org/10.1525/auk.2008.07115

Lima, S. L. 2009. Predators and the breeding bird: behavioral and reproductive flexibility under the risk of predation. Biological Reviews 84:485-513. http://dx.doi.org/10.1111/j.1469-185X.2009.00085. $\mathrm{x}$

Martin, T. E., and J. J. Roper. 1988. Nest predation and nest-site selection of a western population of the Hermit Thrush. Condor 90:51-57. http://dx.doi.org/10.2307/1368432

Martin, T. G., I. Chadès, P. Arcese, P. P. Marra, H. P. Possingham, and D. R. Norris. 2007. Optimal conservation of migratory species. PLOS ONE 2:e751. http://dx.doi.org/10.1371/journal. pone. 0000751

McKellar, A. E., P. P. Marra, P. T. Boag, and L. M. Ratcliffe. 2014. Form, function and consequences of density dependence in a long-distance migratory bird. Oikos 123:356-364. http://dx.doi. org/10.1111/j.1600-0706.2013.00756.x

McLoughlin, P. D., and S. H. Ferguson. 2000. A hierarchical pattern of limiting factors helps explain variation in home range size. Ecoscience 7:123-130.

Moks, K., V. Tilgar, R. L. Thomson, S. Calhim, P. E. Järvistö, W. Schuett, W. Velmala, and T. Laaksonen. 2016. Predator encounters have spatially extensive impacts on parental behaviour in a breeding bird community. Proceedings of the Royal Society B 283:20160020. http://dx.doi.org/10.1098/rspb.2016.0020

Morris, D. W. 2003. How can we apply theories of habitat selection to wildlife conservation and management? Wildlife Research 30:303-319. http://dx.doi.org/10.1071/WR02028
Nagy, L. R., and R. T. Holmes. 2005. Food limits annual fecundity of a migratory songbird: an experimental study. Ecology 86:675-681. http://dx.doi.org/10.1890/04-0155

R Core Team. 2014. R: a language and environment for statistical computing. The R Project for Statistical Computing, Vienna, Austria. [online] URL: http://www.R-project.org/

Reitsma, L., M. Goodnow, M. T. Hallworth, and C. J. Conway. 2010. Canada Warbler (Cardellina canadensis) in A. Poole, editor. The birds of North America online. Cornell Lab of Ornithology, Ithaca, New York, USA. http://dx.doi.org/10.2173/bna.421

Ridley, J., J. Komdeur, and W. J. Sutherland. 2004. Incorporating territory compression into population models. Oikos 105:101-108. http://dx.doi.org/10.1111/j.0030-1299.2004.13013. $\mathrm{x}$

Rodenhouse, N. L., T. S. Sillett, P. J. Doran, and R. T. Holmes. 2003. Multiple density-dependence mechanisms regulate a migratory bird population during the breeding season. Proceedings of the Royal Society of London B: Biological Sciences 270:2105-2110. http://dx.doi.org/10.1098/rspb.2003.2438

Sheehy, J., C. M. Taylor, K. S. McCann, and D. R. Norris. 2010. Optimal conservation planning for migratory animals: integrating demographic information across seasons. Conservation Letters 3:192-202. http://dx.doi.org/10.1111/j.1755-263X.2010.00100. $\mathrm{x}$

Shipley, B. 2009. Confirmatory path analysis in a generalized multilevel context. Ecology 90:363-368. http://dx.doi. org/10.1890/08-1034.1

Shipley, B. 2013. The AIC model selection method applied to path analytic models compared using a d-separation test. Ecology 94:560-564. http://dx.doi.org/10.1890/12-0976.1

Siikamäki, P. 1998. Limitation of reproductive success by food availability and breeding time in Pied Flycatchers. Ecology 79:1789-1796. http://dx.doi.org/10.2307/176797

Sillett, T. S., L. R., Nicholas, and R. T. Holmes. 2004. Experimentally reducing neighbor density affects reproduction and behavior of a migratory songbird. Ecology 85:2467-2477. http://dx.doi.org/10.1890/03-0272

Stamps, J. A. 1990. The effect of contender pressure on territory size and overlap in seasonally territorial species. American Naturalist 135:614-632. http://dx.doi.org/10.1086/285065

Sutherland, W. J. 1996. Predicting the consequences of habitat loss for migratory populations. Proceedings of the Royal Society B: Biological Sciences 263:1325-1327. http://dx.doi.org/10.1098/ rspb.1996.0194

Trevelline, B. K., S. C. Latta, L. C. Marshall, T. Nuttle, and B. A. Porter. 2016. Molecular analysis of nestling diet in a long-distance Neotropical migrant, the Louisiana Waterthrush (Parkesia motacilla). Auk 133:415-428. http://dx.doi.org/10.1642/AUK-15-222.1

Van Horne, B. 1983. Density as a misleading indicator of habitat quality. Journal of Wildlife Management 47:893-901. http://dx. doi.org/10.2307/3808148 
Venier, L. A., S. B. Holmes, J. L. Pearce, and R. E. Fournier. 2012. Misleading correlations: the case of the Canada Warbler and spruce budworm. Journal of Wildlife Management 76:294-298. http://dx.doi.org/10.1002/jwmg.257

Webster, M. S., P. P. Marra, S. M. Haig, S. Bensch, and R. T. Holmes. 2002. Links between worlds: unraveling migratory connectivity. Trends in Ecology and Evolution 17:76-83. http://dx. doi.org/10.1016/S0169-5347(01)02380-1

Zanette, L. Y., A. F. White, M. C. Allen, and M. Clinchy. 2011. Perceived predation risk reduces the number of offspring songbirds produce per year. Science 334:1398-1401. http://dx.doi. org/10.1126/science. 1210908 


\title{
Appendix 1
}

\section{Factors driving territory size and breeding success in a threatened migratory songbird, the Canada warbler}

\author{
D. T. Tyler Flockhart, Greg W. Mitchell, Richard G. Krikun, and Erin M. Bayne \\ Corresponding author: dflockha@uoguelph.ca
}

\section{Parameter selection, model building, and validation}

Prior to model fitting, we visually inspected territory size estimates and measurements of conspecific density, percent shrub cover, shrub density, insect abundance, and percent canopy trees that were conifer for outliers (Table S1). We found that one bird had a territory size that was consistently much larger than all other birds across all $\mathrm{KDE}$ contours (e.g., min 50\% KDE = 0.12 ha, median $50 \% \mathrm{KDE}=0.50$ ha, outlying value $=2.38$ ha, second largest $50 \% \mathrm{KDE}$ value $=$ $0.97 \mathrm{ha}$ ), and was subsequently removed from all analyses. We also found one bird had more than double the percent of canopy trees that were conifer in its territory relative to other birds (i.e., $\min$ and median $=0$, outlying value $=59 \%$, second largest value $=22 \%$ ). However, the effect of proportion conifer and its importance as assessed using AICc (MuMIn package; Barton 2015) for all paths in which it was included changed little when the outlying value was removed. Therefore, we opted to retain this bird in our final modeling procedure. To assess potential nonlinear relationships we individually fit quadratic terms for each continuous covariate included in each global model and assessed their importance using AICc. We did not find any evidence for the inclusion of quadratic terms, with the exception of percent canopy trees that were conifer in 
relation to both territory size and breeding success. However, these relationships were both driven by the outlying value identified above and disappeared when this outlying value was removed. Therefore, we did not include a quadratic term for percent canopy trees that were conifer in our final modeling exercise. For all models, we visually assessed model fit using residual plots (quantile-quantile plots and density plots for linear models, as well as plots of residuals versus fitted values and plots of residuals versus each covariate for all models).

To determine the best metric for shrub cover for our analyses, i.e., shrub density, percent shrub cover or percent shrub cover that was conifer, we separately evaluated the effects of each measurement on territory size across all measured $\mathrm{KDE}$ contours $(\mathrm{n}=10$, range $=0.50$ to 0.95$)$ using linear mixed-effects models, where we specified a random effect for study site to account for spatial autocorrelation. First, we standardized all KDE contour measurements as well as each metric of shrub cover, and compared effect sizes amongst contours and metrics. We found that effect sizes increased as KDE contour size decreased (from 95 to 50) for each metric (shrub density: 0.07 to 0.16 , percent shrub cover: -0.42 to -0.48 , percent shrub cover that was conifer: 0.21 to -0.26 ). Second, given that effect sizes were largest for the KDE50 contour for each metric, we compared AICc values amongst each KDE50 contour model (AICc for shrub density $=92.92$, percent shrub cover $=85.73$, percent shrub cover that was conifer $=91.55)$. Together, this exercise indicated that percent shrub cover was the best metric for shrub cover.

Given debate around the appropriate KDE contour to use to characterize territory size in general (see Börger et al. 2006), we also evaluated the most appropriate KDE contour for all predictor variables in the context of our study by fitting linear mixed effects models for each KDE contour, where KDEs were modelled as a function of insect abundance, conspecific density, squirrel presence/absence, shrub cover, site context, percent canopy trees that were 
conifer, and year, with a random effect specified for study site. We found that that model residuals were best for the $50 \% \mathrm{KDE}$ contour and that parameter estimates were in general, similar amongst models, therefore, we used the 50\% KDEs in all subsequent analyses and hereafter refer to this variable as 'territory size'.

\section{Literature Cited}

Barton, K. 2015. Multi-model inference. R package version 1.15.1

Börger, L., N. Franconi, G. De Michele, A. Gantz, F. Meschi, A. Manica, S. Lovari, and T. Coulson. 2006. Effects of sampling regime on the mean and variance of home range size estimates. Journal of Animal Ecology 75:1393-1405. 
Figure A1.1

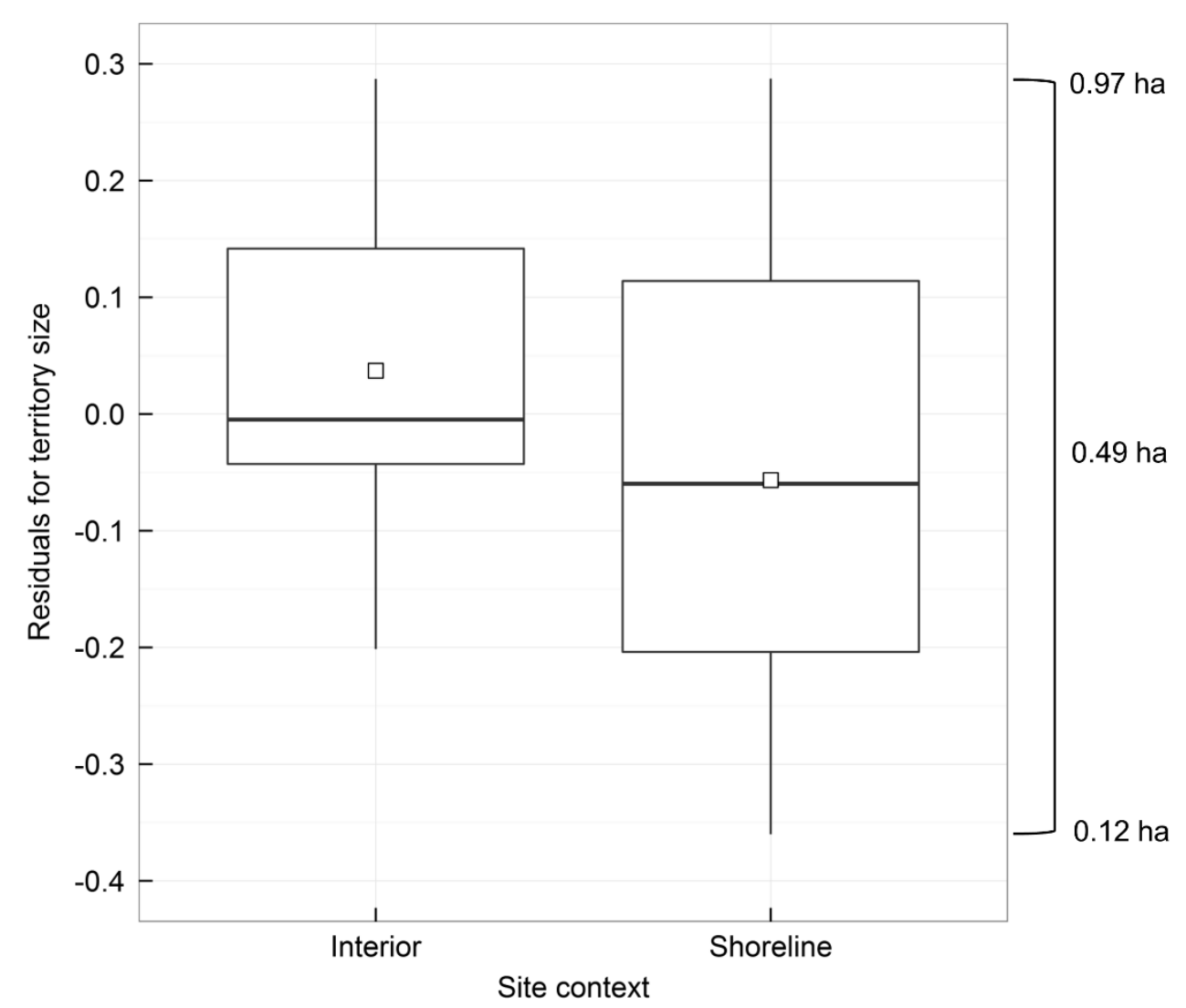

Figure A1.1. Partial residual boxplot illustrating relationship between site context and territory size. The solid black horizontal line in each box represents the median and the square in each box represents the mean. The area above and below the horizontal line represents the 50th to the 75th and the 25th to the 50th percentiles, respectively. The vertical lines or whiskers extend to the highest and lowest values contained within 1.5 times the interquartile range of the data. The bracket on the right, from top to bottom, illustrates the maximum, median, and minimum measurements for territory size (ha; 50\% KDE contour), respectively. 
Figure A1.2.

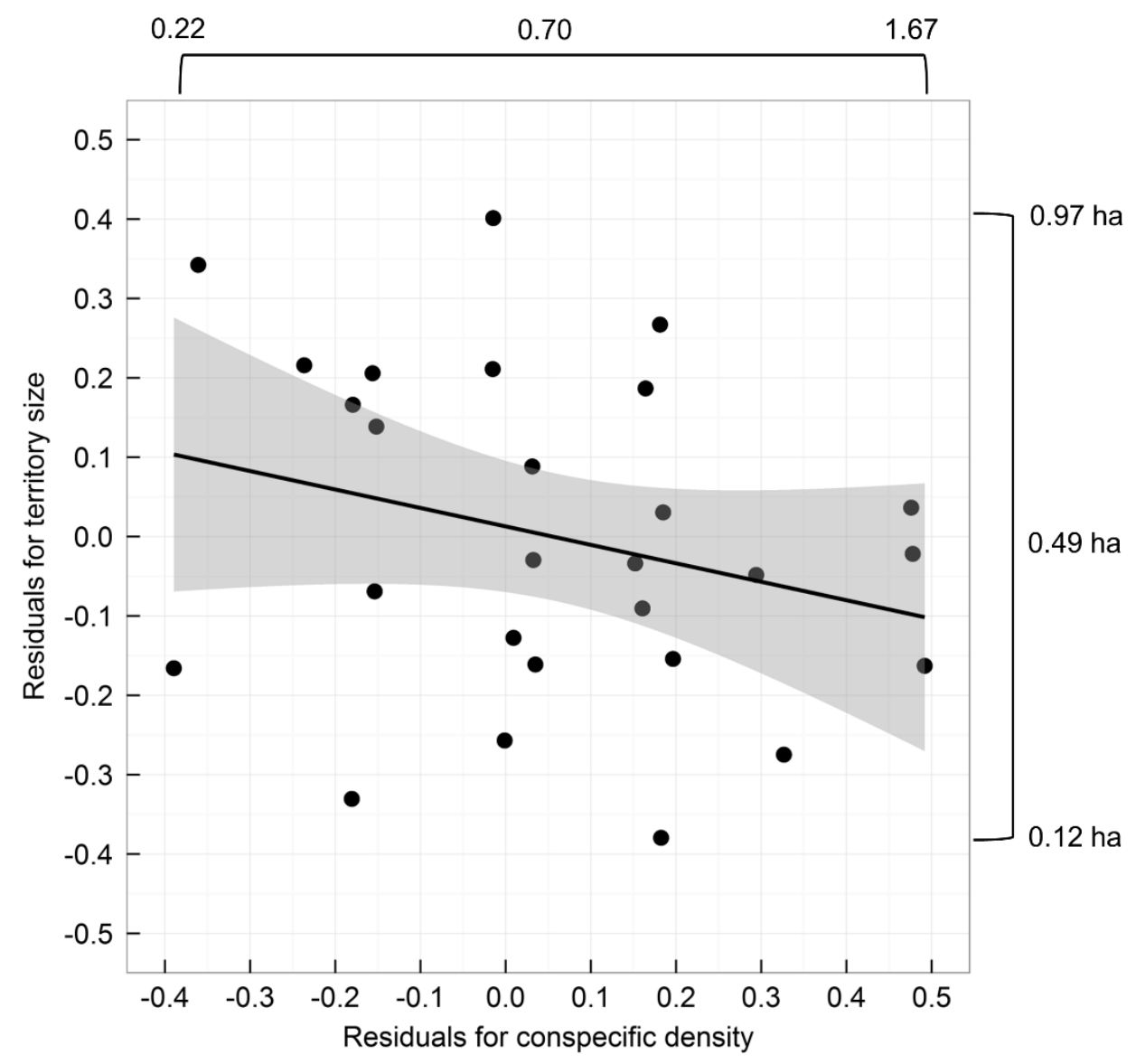

Figure A1.2. Partial residual plot illustrating relationship between conspecific density and territory size. The grey area represents the 95\% confidence interval associated with the fitted values. The bracket on the top, from left to right, illustrates the minimum, median, and maximum conspecific density, respectively. The bracket on the right, from top to bottom, illustrates the maximum, median, and minimum measurements for territory size (ha; 50\% KDE contour), respectively. 
Table A1.1. Data set used in the paper of the territory attributes of Canada warblers at Slave Lake, Alberta, 2012-2013.

ID Year Site StudyArea Npoints KDE50_ha KDE55_ha KDE60_ha KDE65_ha KDE70_ha KDE75_ha KDE80_ha KDE85_ha KDE90_ha KDE95_ha PercentShrubs PercentConiferTree Insects Squirrrel ConspecificDensity BreedingSuccess

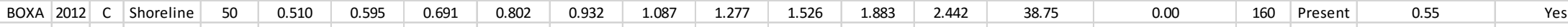
BPXA 2013 D Interior BRXA 2012 D Interior 48 BWXA 2012 D BYXA 2012 B 1 Interior MBXA 2012 A Shoreline \begin{tabular}{l|l|l|l|l|l|l} 
MMXA 2012 & B & Interior & 58 & \\
MWXA 2012 & D & Interior
\end{tabular} \begin{tabular}{|l|l|l|l|}
\hline MYXA 2012 & D & Interior \\
\hline
\end{tabular} OMXA 2013 D 1 Interior \begin{tabular}{|l|l|l|l|}
\hline OPXA & 2013 & B & Interior \\
\hline ORXA & 2013 & A & Shoreline \\
\hline
\end{tabular} OWXA 2013 C Shoreline PMXA 2013 A Shoreline \begin{tabular}{|l|l|l|l|}
\hline PPXA & 2013 & C & Shoreline \\
\hline
\end{tabular} \begin{tabular}{|l|l|l|l|}
\hline PWXA 2013 & A & Shoreline \\
\hline PYXA & 2012 & A & Shoreline \\
\hline
\end{tabular} RMXA 2012 A Shoreline ROXA 2012 A Shoreline RPXA 2012 C Shoreline

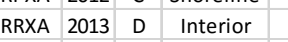

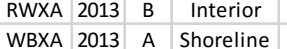
$\begin{array}{llll}\text { WBXA } 2013 & \text { A } & \text { Shoreline } \\ \text { WMXA } 2013 & \text { C } & \text { Shoreline }\end{array}$ WOXA 2012 B Interior \begin{tabular}{l|l|l|l|}
\hline WPXA 2012 & C & Shoreline \\
\hline YBXA & 2012 & A & Shorline
\end{tabular} \begin{tabular}{|l|l|l|l|}
\hline YBXA & 2012 & A & Shoreline \\
\hline YMXA & 2013 & C & Shoreline \\
\hline YRXA & 2012 & C & Shoreline \\
\hline
\end{tabular} YRXA 2012 C Shoreline \begin{tabular}{ll|l|l|} 
YWXA 2013 & B & Interior
\end{tabular}

\begin{tabular}{|c|c|c|c|c|c|c|c|c|c|c|c|c|c|c|c|c|}
\hline 50 & 0.510 & 0.595 & 0.691 & 0.802 & 0.932 & 1.087 & 1.277 & 1.526 & 1.883 & 2.442 & 38.75 & 0.00 & 160 & Present & 0.55 & Yes \\
\hline 48 & 0.916 & 1.131 & 1.377 & 1.661 & 1.988 & 2.379 & 2.835 & 3.392 & 4.131 & 5.294 & 36.25 & 13.33 & 41 & Absent & 0.22 & Yes \\
\hline 48 & 0.356 & 0.415 & 0.484 & 0.566 & 0.667 & 0.793 & 0.948 & 1.135 & 1.373 & 1.722 & 53.75 & 0.00 & 287 & Present & 0.75 & No \\
\hline 48 & 0.523 & 0.603 & 0.690 & 0.786 & 0.895 & 1.021 & 1.173 & 1.367 & 1.634 & 2.009 & 36.25 & 59.09 & 287 & Present & 0.75 & Yes \\
\hline 25 & 0.246 & 0.286 & 0.332 & 0.386 & 0.452 & 0.531 & 0.626 & 0.746 & 0.910 & 1.173 & 82.5 & 0.00 & 161 & Absent & 1.67 & No \\
\hline 53 & 0.119 & 0.142 & 0.167 & 0.198 & 0.236 & 0.288 & 0.359 & 0.449 & 0.569 & 0.753 & 41.25 & 0.00 & 58 & Absent & 1.00 & Yes \\
\hline 58 & 0.650 & 0.756 & 0.874 & 1.008 & 1.161 & 1.337 & 1.546 & 1.810 & 2.152 & 2.670 & 50 & 0.00 & 161 & Absent & 1.67 & Yes \\
\hline 47 & 0.644 & 0.749 & 0.868 & 1.007 & 1.171 & 1.372 & 1.626 & 1.966 & 2.416 & 3.055 & 37.5 & 9.52 & 287 & Absent & 0.75 & Yes \\
\hline 52 & 0.586 & 0.678 & 0.780 & 0.896 & 1.029 & 1.187 & 1.372 & 1.600 & 1.902 & 2.351 & 61.25 & 0.00 & 287 & Present & 0.75 & No \\
\hline 49 & 0.541 & 0.668 & 0.808 & 0.964 & 1.138 & 1.344 & 1.590 & 1.892 & 2.303 & 2.950 & 12.5 & 22.22 & 41 & Present & 0.22 & Yes \\
\hline 44 & 0.481 & 0.555 & 0.638 & 0.730 & 0.834 & 0.956 & 1.100 & 1.271 & 1.491 & 1.827 & 81.25 & 0.00 & 55 & Absent & 0.67 & Yes \\
\hline 51 & 0.688 & 0.792 & 0.908 & 1.039 & 1.192 & 1.377 & 1.608 & 1.919 & 2.380 & 3.183 & 37.5 & 2.00 & 42 & Absent & 0.64 & Yes \\
\hline 20 & 0.135 & 0.157 & 0.184 & 0.216 & 0.255 & 0.309 & 0.381 & 0.472 & 0.596 & 0.798 & 78.75 & 5.88 & 26 & Absent & 0.55 & No \\
\hline 42 & 0.208 & 0.244 & 0.287 & 0.338 & 0.402 & 0.482 & 0.586 & 0.725 & 0.908 & 1.198 & 35 & 14.63 & 42 & Absent & 0.64 & No \\
\hline 49 & 0.971 & 1.123 & 1.295 & 1.492 & 1.724 & 2.004 & 2.345 & 2.764 & 3.348 & 4.352 & 30 & 0.00 & 26 & Absent & 0.55 & Yes \\
\hline 44 & 0.429 & 0.509 & 0.609 & 0.733 & 0.893 & 1.088 & 1.321 & 1.615 & 2.019 & 2.635 & 85 & 0.00 & 42 & Absent & 0.64 & No \\
\hline 53 & 0.498 & 0.585 & 0.684 & 0.796 & 0.927 & 1.087 & 1.277 & 1.506 & 1.801 & 2.240 & 46.25 & 0.00 & 58 & Absent & 1.00 & Yes \\
\hline 39 & 0.298 & 0.352 & 0.415 & 0.487 & 0.574 & 0.674 & 0.793 & 0.940 & 1.134 & 1.441 & 33.75 & 9.09 & 161 & Present & 1.67 & No \\
\hline 47 & 0.782 & 0.966 & 1.187 & 1.439 & 1.740 & 2.093 & 2.514 & 3.036 & 3.735 & 4.814 & 38.75 & 12.50 & 58 & Absent & 1.00 & No \\
\hline 50 & 0.420 & 0.496 & 0.587 & 0.698 & 0.829 & 0.986 & 1.183 & 1.442 & 1.797 & 2.343 & 45 & 0.00 & 160 & Present & 0.73 & Yes \\
\hline 46 & 0.678 & 0.814 & 0.976 & 1.171 & 1.411 & 1.701 & 2.043 & 2.458 & 2.986 & 3.765 & 71.25 & 0.00 & 41 & Present & 0.22 & Yes \\
\hline 49 & 0.789 & 0.906 & 1.038 & 1.189 & 1.368 & 1.585 & 1.859 & 2.212 & 2.675 & 3.391 & 15 & 0.00 & 55 & Absent & 0.67 & Yes \\
\hline 48 & 0.122 & 0.152 & 0.191 & 0.240 & 0.302 & 0.374 & 0.460 & 0.568 & 0.713 & 0.947 & 90 & 20.00 & 42 & Absent & 0.64 & No \\
\hline 56 & 0.789 & 0.937 & 1.104 & 1.292 & 1.503 & 1.741 & 2.018 & 2.341 & 2.742 & 3.337 & 28.75 & 0.00 & 26 & Absent & 0.55 & No \\
\hline 60 & 0.568 & 0.671 & 0.790 & 0.929 & 1.096 & 1.293 & 1.520 & 1.791 & 2.144 & 2.689 & 53.75 & 0.00 & 161 & Absent & 1.67 & Yes \\
\hline 53 & 0.123 & 0.145 & 0.170 & 0.197 & 0.227 & 0.261 & 0.301 & 0.347 & 0.407 & 0.499 & 52.5 & 9.52 & 160 & Present & 0.73 & No \\
\hline 44 & 0.163 & 0.206 & 0.258 & 0.324 & 0.405 & 0.497 & 0.606 & 0.740 & 0.925 & 1.214 & 70 & 3.70 & 58 & Absent & 1.00 & Yes \\
\hline 51 & 0.139 & 0.169 & 0.205 & 0.247 & 0.300 & 0.365 & 0.443 & 0.535 & 0.654 & 0.831 & 57.5 & 0.00 & 26 & Absent & 0.55 & Yes \\
\hline 54 & 0.286 & 0.339 & 0.397 & 0.463 & 0.542 & 0.643 & 0.776 & 0.938 & 1.144 & 1.438 & 47.5 & 0.00 & 160 & Present & 0.73 & Yes \\
\hline 47 & 0.391 & 0.470 & 0.567 & 0.681 & 0.810 & 0.958 & 1.138 & 1.360 & 1.642 & 2.066 & 85 & 0.00 & 55 & Absent & 0.67 & Yes \\
\hline
\end{tabular}


Table A1.2. AIC model selection results for path models examining relationships between factors hypothesized to effect territory size and breeding success. K represents the number of parameters in each path model. W and Cumulative W represent Akaike weights and cumulative model weights, respectively. Fisher's $C$ statistic $=-2 * \ln ($ model likelihood). Path model equations represent individual regression equations or sub-models comprising each path model, where each predictor variable represents a path in the path model. $\neq$ indicates random effect included in sub-model for study site.

\begin{tabular}{|c|c|c|c|c|c|c|}
\hline Path model equations & K & AIC & $\Delta \mathrm{AIC}$ & W & $\begin{array}{c}\text { Cumulative } \\
\text { W }\end{array}$ & $\begin{array}{c}\text { Fisher's } \\
\text { C }\end{array}$ \\
\hline $\begin{array}{l}\text { insect abundance }=\text { intercept }+ \text { site context }+ \text { year } \\
\text { conspecific density }=\text { intercept } \\
\text { łsquirrel presence/absence }=\text { intercept } \\
\text { łproportion trees conifer }=\text { intercept } \\
\text { łpercent shrub cover }=\text { intercept }+ \text { proportion trees conifer }\end{array}$ & 11 & 49.30 & 0 & 0.27 & 0.27 & 27.30 \\
\hline insect abundance $=$ intercept + site context + year & 15 & 50.36 & 1.06 & 0.16 & 0.43 & 20.36 \\
\hline
\end{tabular}




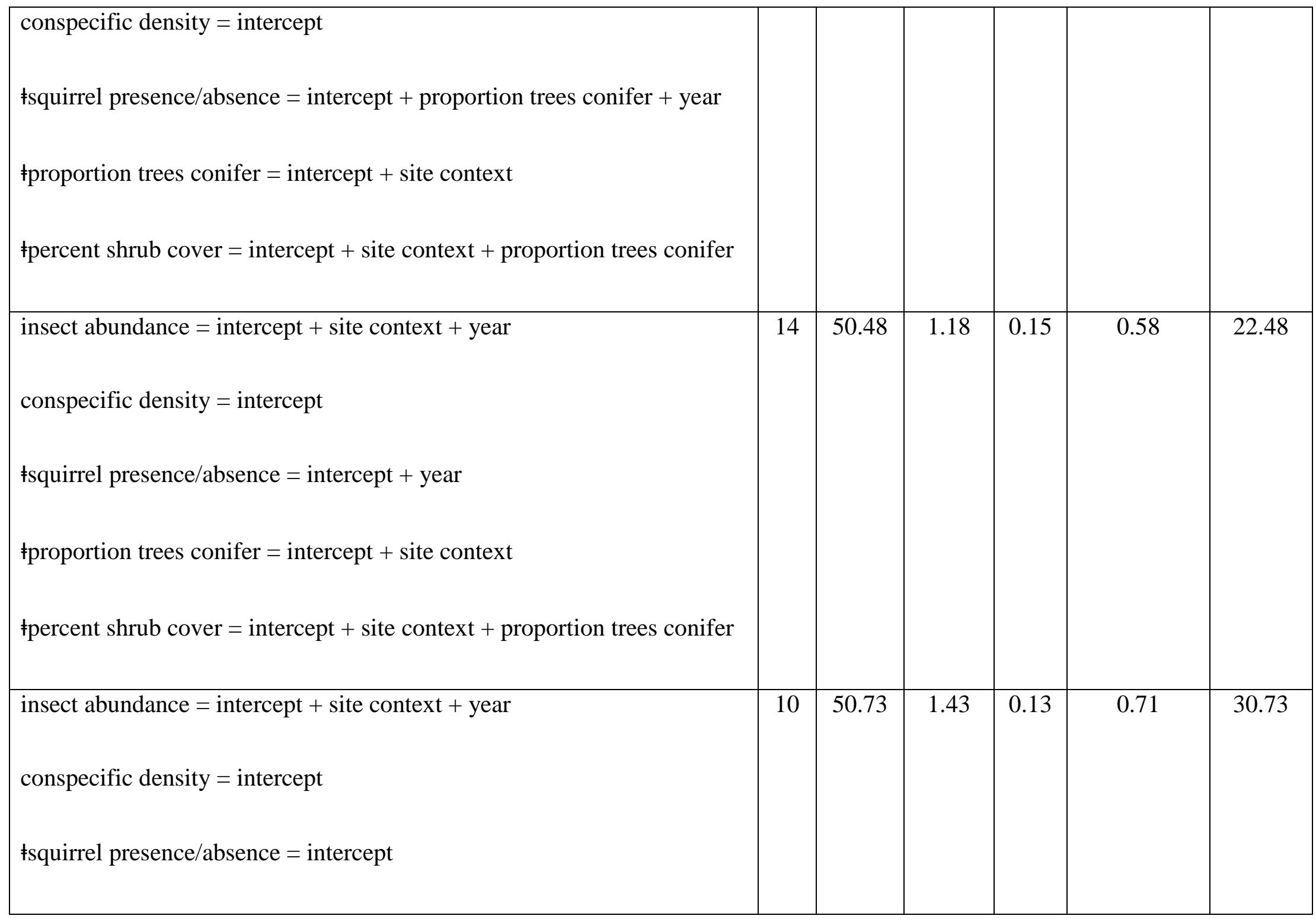




\begin{tabular}{|c|c|c|c|c|c|c|}
\hline $\begin{array}{l}\text { fproportion trees conifer = intercept } \\
\text { łpercent shrub cover = intercept }\end{array}$ & & & & & & \\
\hline $\begin{array}{l}\text { insect abundance }=\text { intercept }+ \text { site context }+ \text { year } \\
\text { conspecific density }=\text { intercept } \\
\text { łsquirrel presence/absence }=\text { intercept } \\
\text { łproportion trees conifer }=\text { intercept }+ \text { site context } \\
\text { fpercent shrub cover }=\text { intercept }+ \text { site context }+ \text { proportion trees conifer }\end{array}$ & 13 & 51.01 & 1.71 & 0.12 & 0.83 & 25.01 \\
\hline $\begin{array}{l}\text { insect abundance }=\text { intercept }+ \text { site context }+ \text { year } \\
\text { conspecific density }=\text { intercept } \\
\text { łsquirrel presence/absence }=\text { intercept } \\
\text { łproportion trees conifer }=\text { intercept } \\
\text { łpercent shrub cover }=\text { intercept }+ \text { site context }+ \text { proportion trees conifer }\end{array}$ & 12 & 51.12 & 1.82 & 0.11 & 0.94 & 27.12 \\
\hline
\end{tabular}




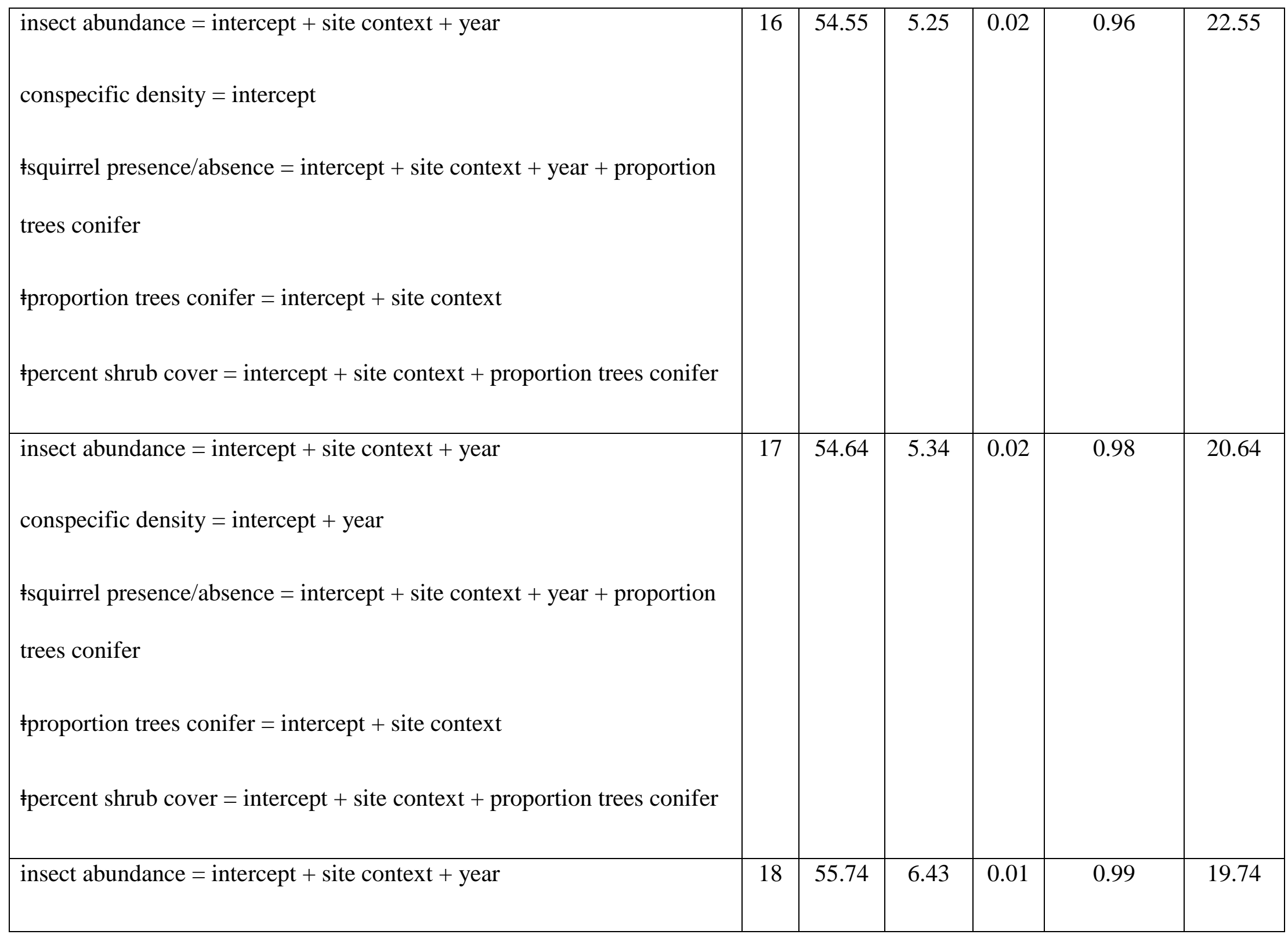




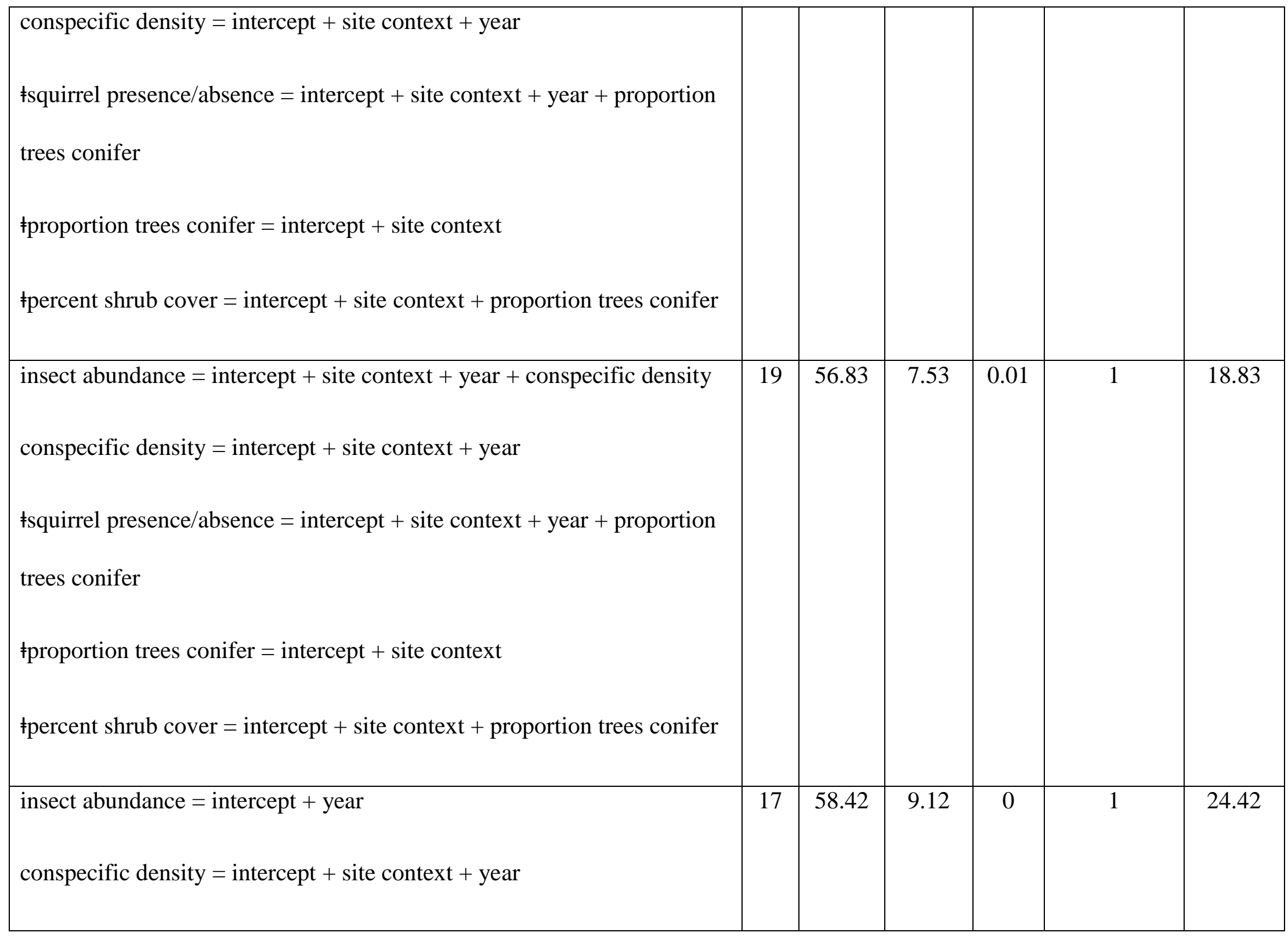




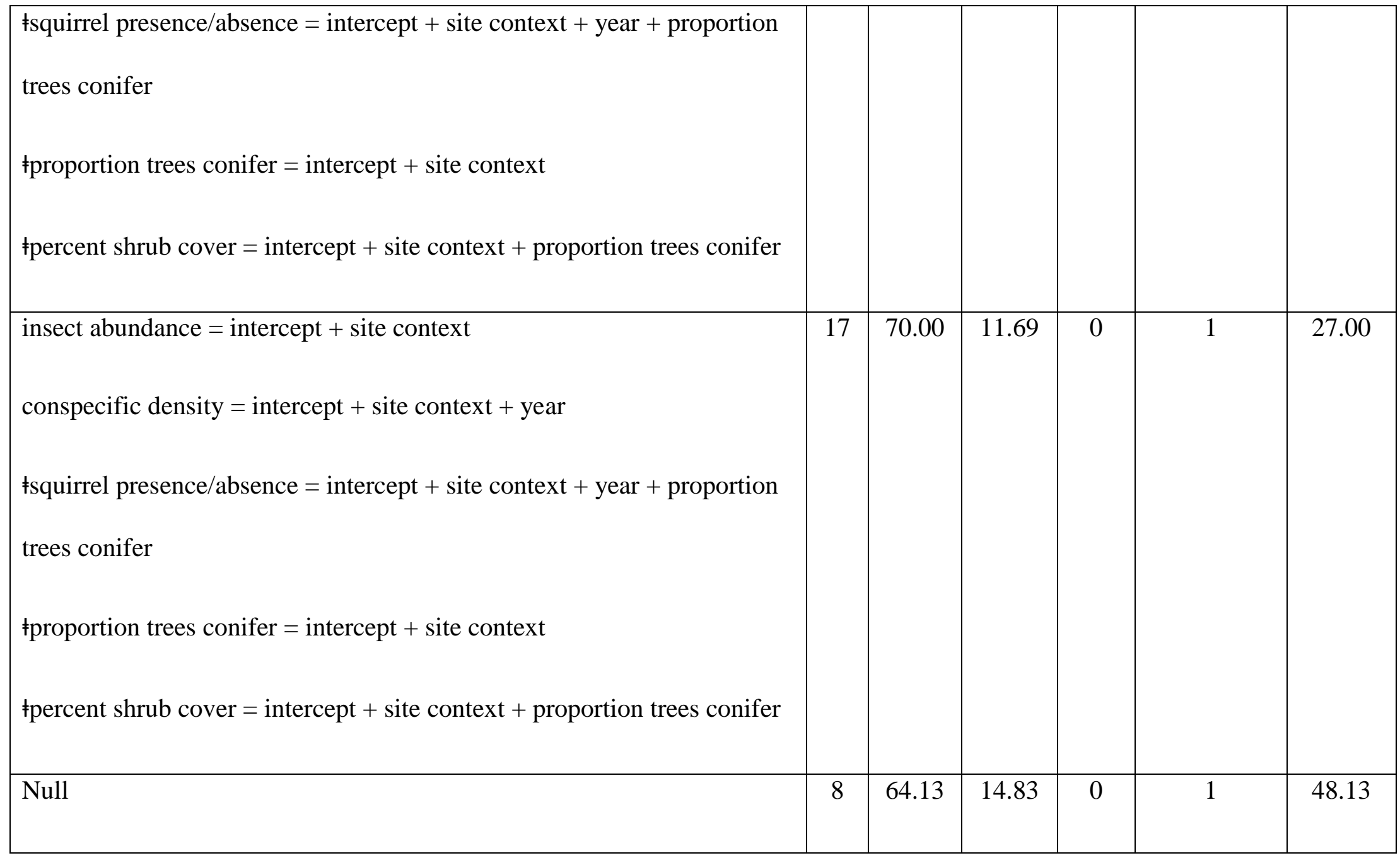


Table A1.3. AIC model selection results for path models examining factors hypothesized to effect kernel density estimates of territory size and breeding success. K represents the number of parameters in each path model. W and Cumulative W represent Akaike weights and cumulative model weights, respectively. Fisher's $\mathrm{C}$ statistic $=-2 * \ln ($ model likelihood). Path model equations represent individual regression equations or sub-models comprising each path model, where each predictor variable represents a path in the path model.

Null model represents the top model with all paths to territory size and breeding success removed. $¥$ indicates random effect included in sub-model for study site.

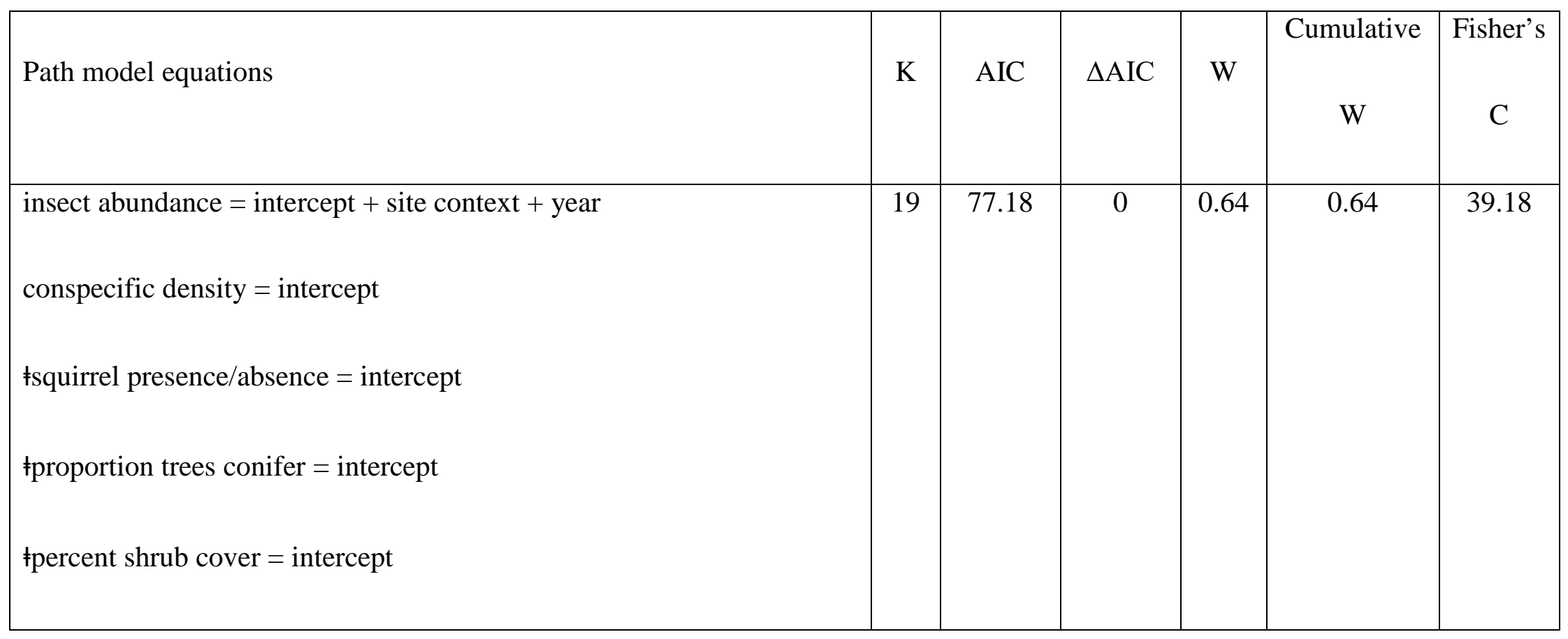




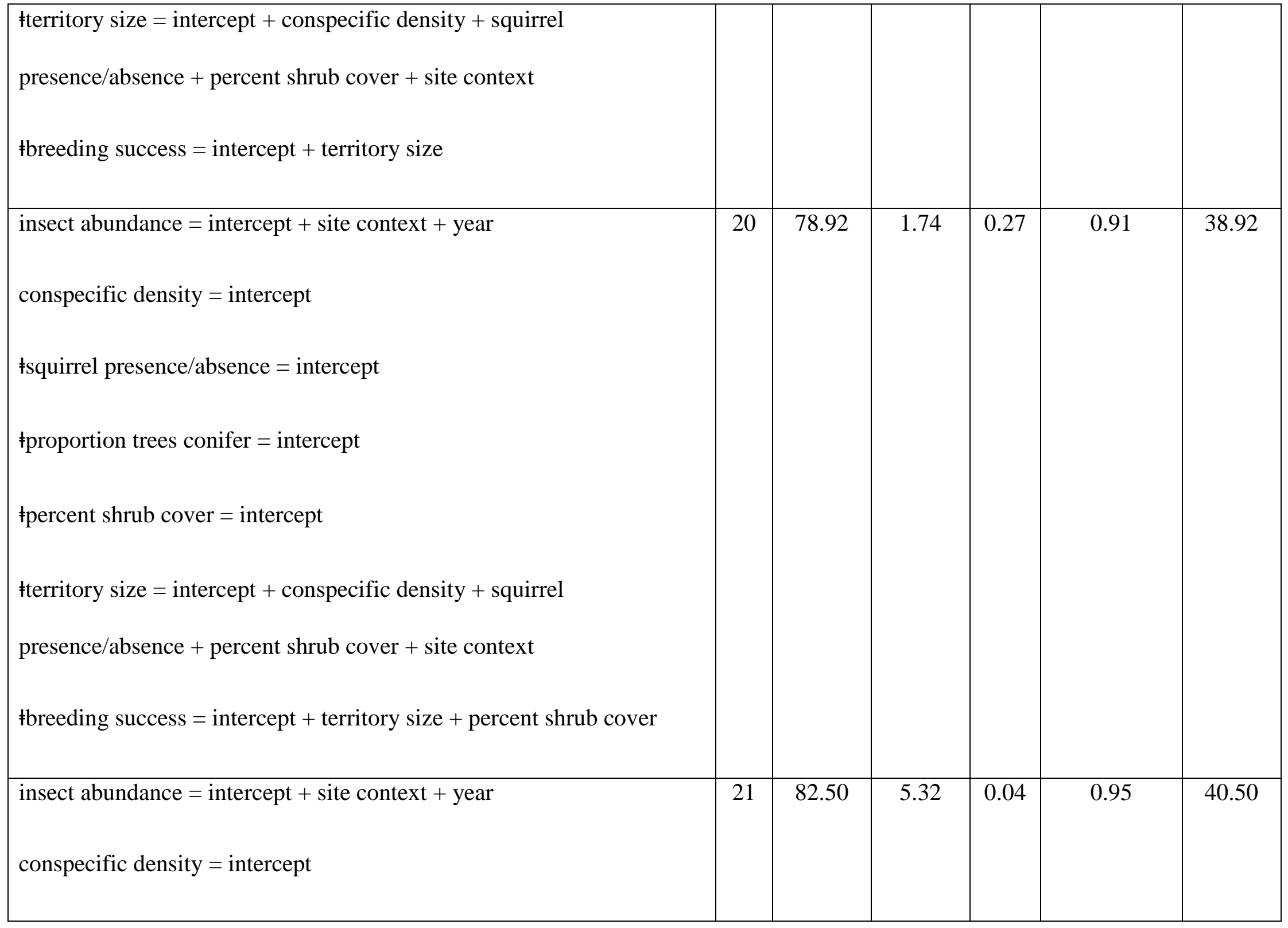




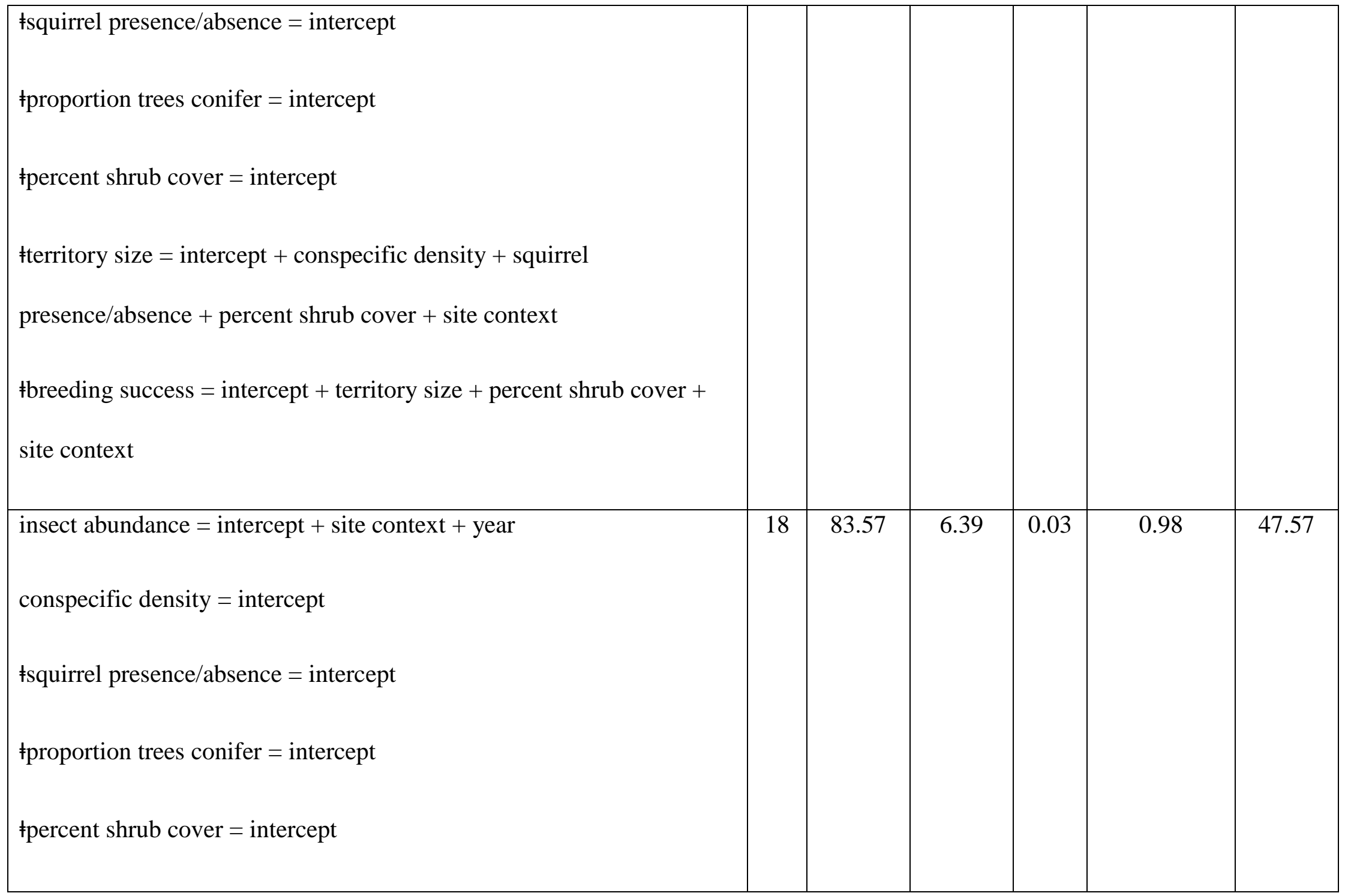




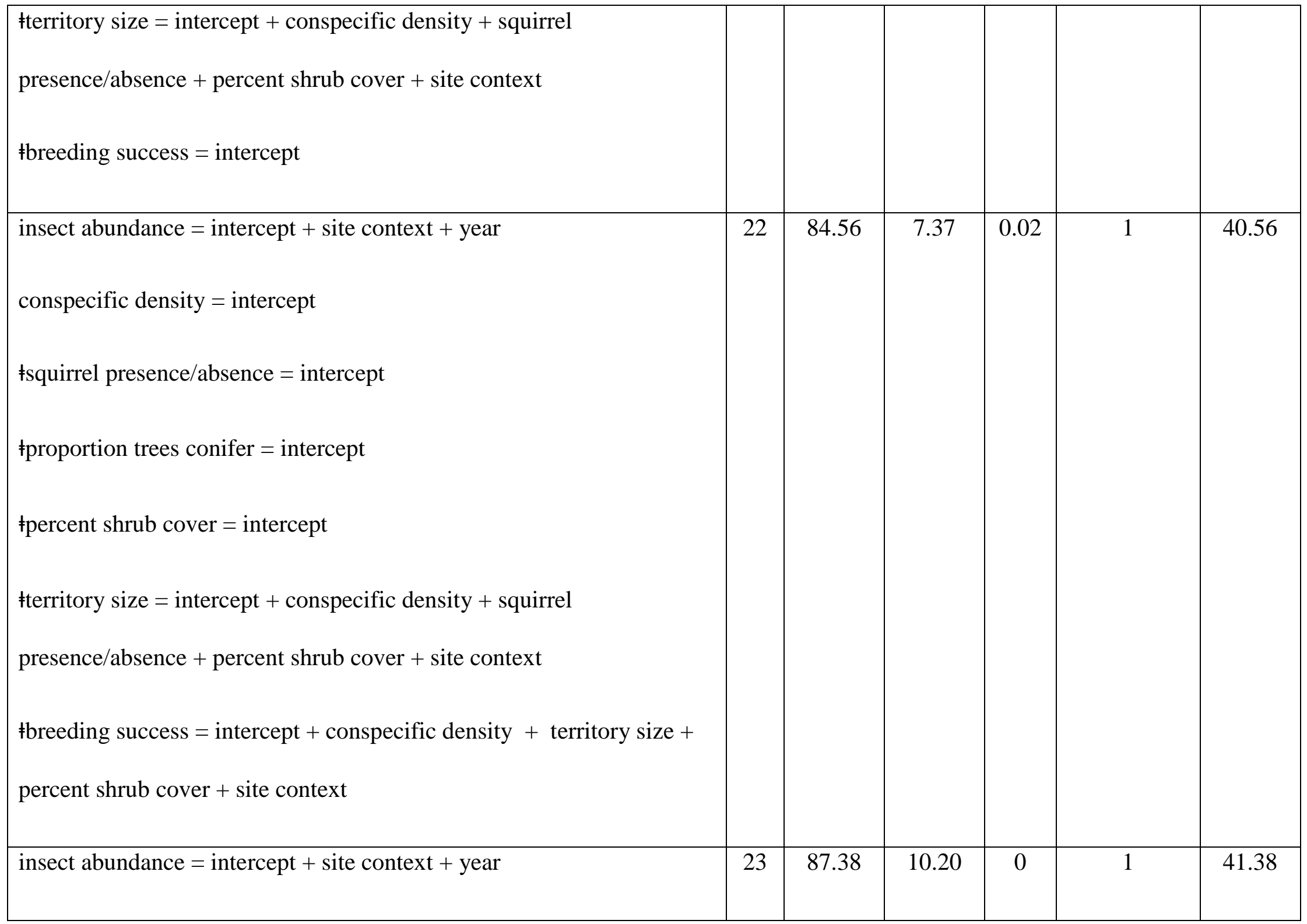




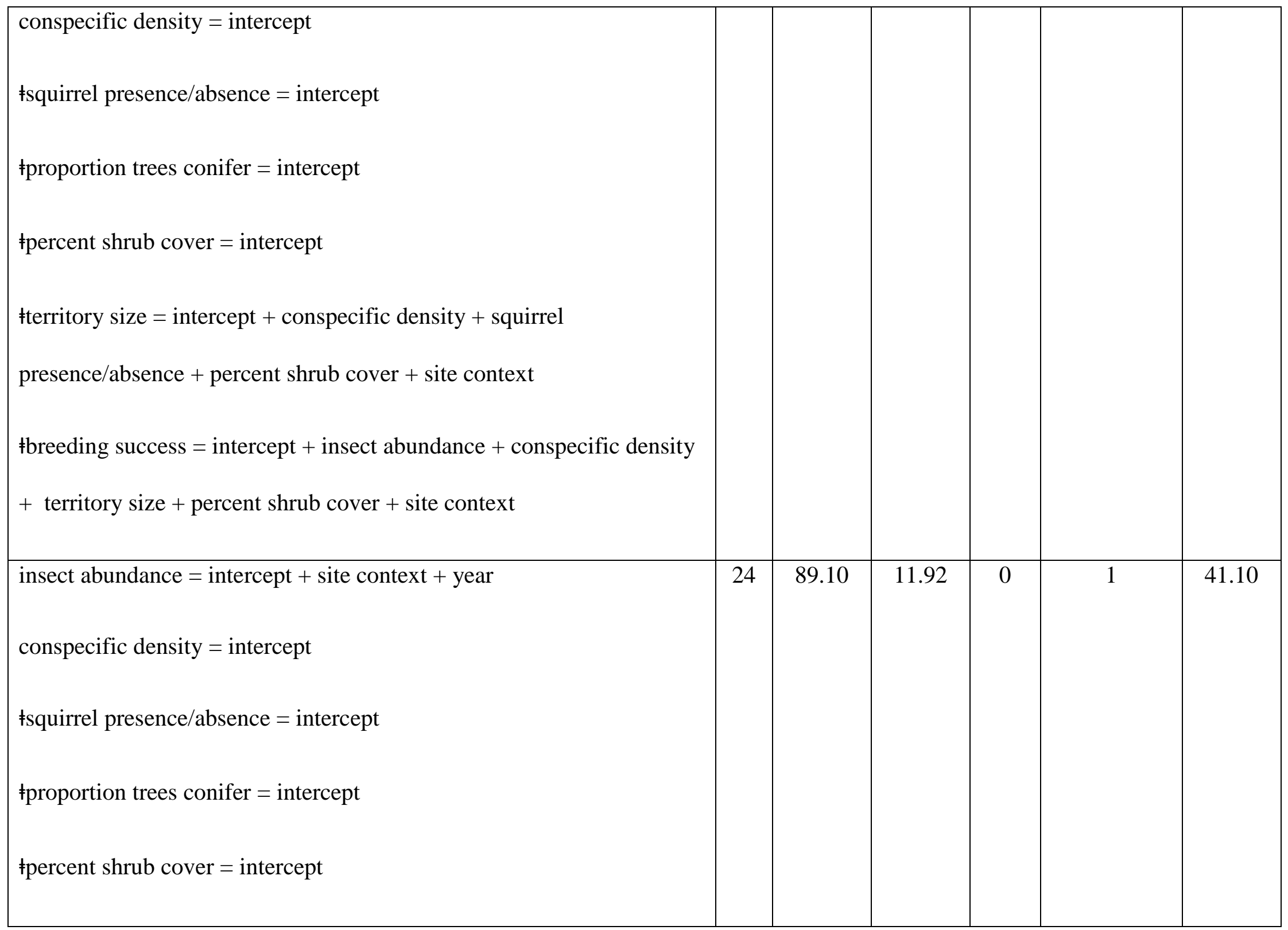




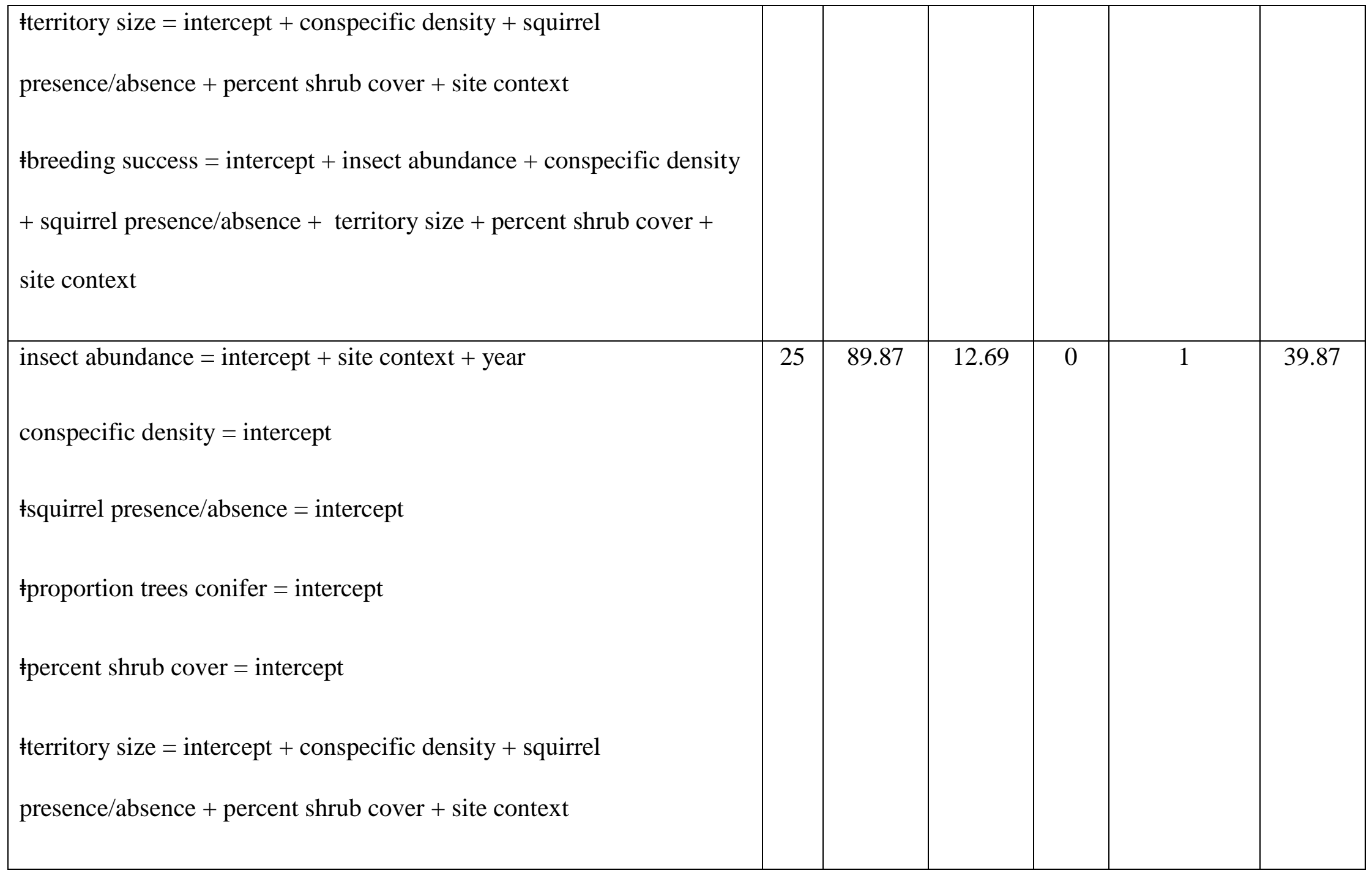




\begin{tabular}{|c|c|c|c|c|c|c|}
\hline $\begin{array}{l}\text { fbreeding success }=\text { intercept }+ \text { insect abundance }+ \text { conspecific density } \\
+ \text { squirrel presence/absence }+ \text { territory size }+ \text { percent shrub cover }+ \\
\text { proportion trees conifer }+ \text { site context }\end{array}$ & & & & & & \\
\hline $\begin{array}{l}\text { insect abundance }=\text { intercept }+ \text { site context }+ \text { year } \\
\text { conspecific density }=\text { intercept } \\
\text { łsquirrel presence/absence }=\text { intercept } \\
\text { łproportion trees conifer }=\text { intercept } \\
\text { łpercent shrub cover }=\text { intercept } \\
\text { łterritory size }=\text { intercept }+ \text { conspecific density }+ \text { squirrel } \\
\text { presence/absence }+ \text { percent shrub cover }+ \text { site context }+ \text { year } \\
\text { łbreeding success }=\text { intercept }+ \text { insect abundance }+ \text { conspecific density } \\
+ \text { squirrel presence/absence }+ \text { territory size }+ \text { percent shrub cover }+ \\
\text { proportion trees conifer }+ \text { site context }\end{array}$ & 26 & 91.32 & 14.14 & 0 & 1 & 39.32 \\
\hline
\end{tabular}




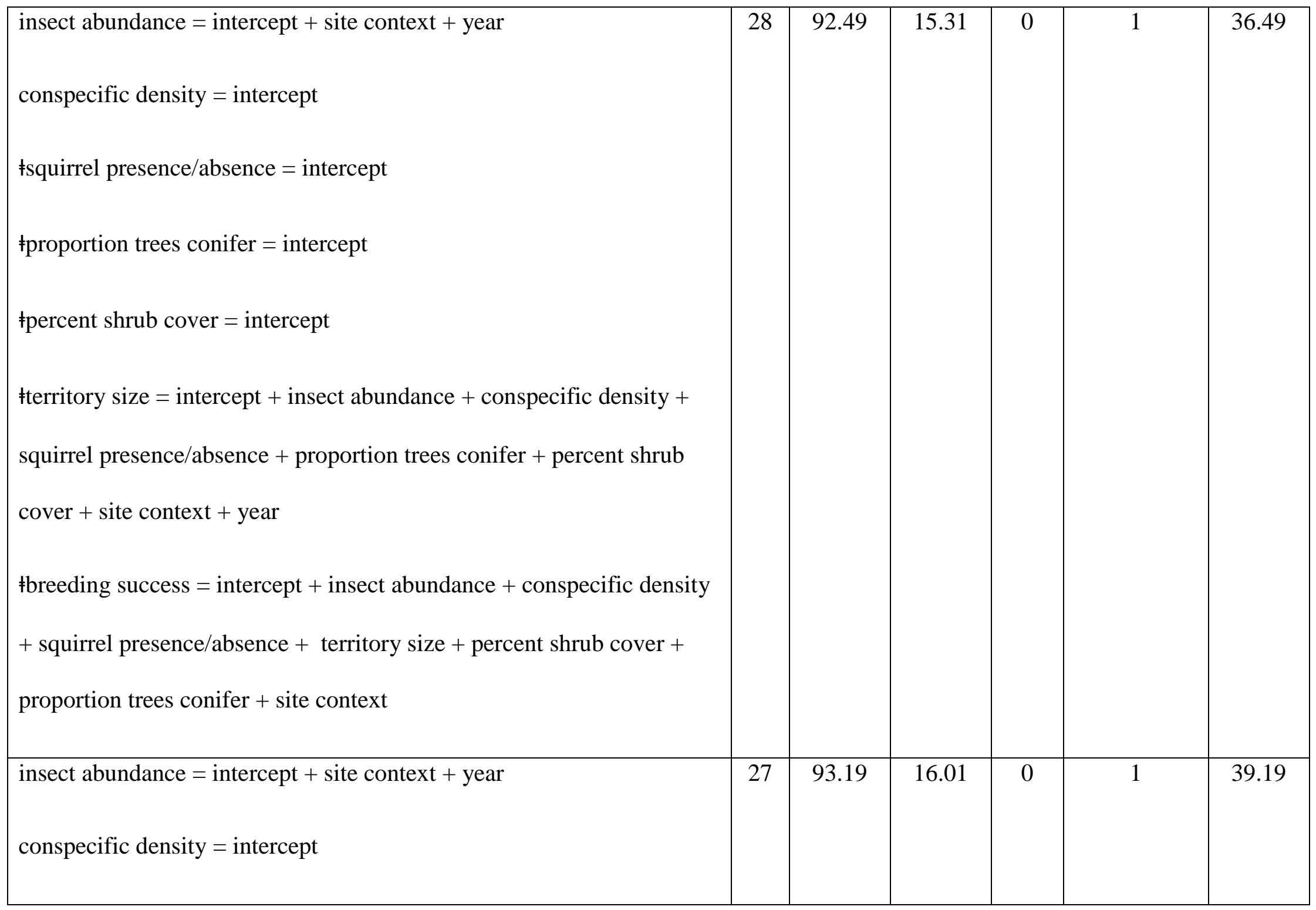




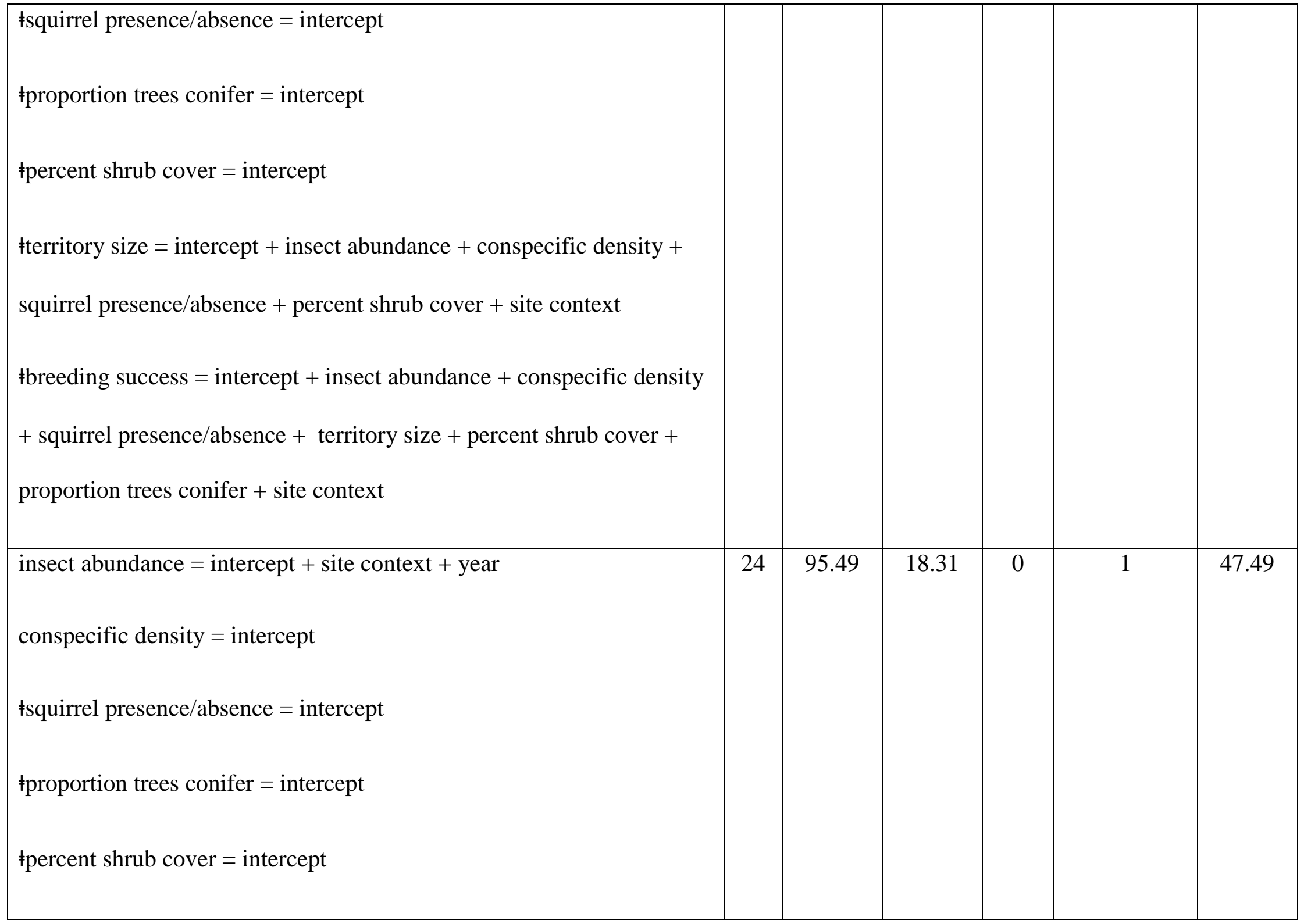




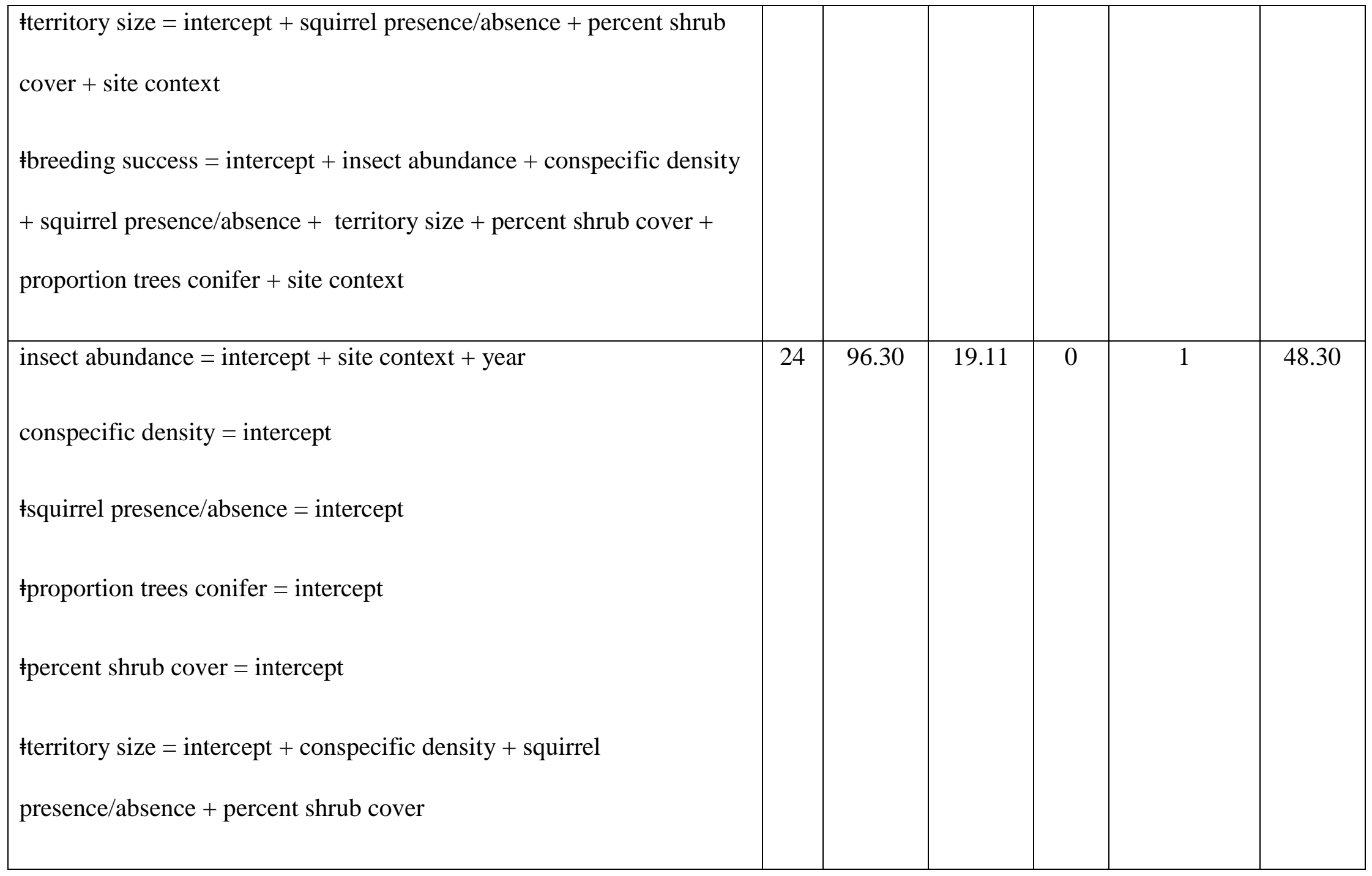




\begin{tabular}{|c|c|c|c|c|c|c|}
\hline $\begin{array}{l}\text { fbreeding success }=\text { intercept }+ \text { insect abundance }+ \text { conspecific density } \\
+ \text { squirrel presence/absence }+ \text { territory size }+ \text { percent shrub cover }+ \\
\text { proportion trees conifer }+ \text { site context }\end{array}$ & & & & & & \\
\hline Null & 14 & 96.49 & 19.30 & 0 & 1 & 68.49 \\
\hline $\begin{array}{l}\text { insect abundance }=\text { intercept }+ \text { site context }+ \text { year } \\
\text { conspecific density }=\text { intercept } \\
\text { łsquirrel presence/absence }=\text { intercept } \\
\text { łproportion trees conifer = intercept } \\
\text { łpercent shrub cover = intercept } \\
\text { łterritory size = intercept }+ \text { conspecific density }+ \text { squirrel } \\
\text { presence/absence }+ \text { site context }\end{array}$ & 24 & 98.71 & 21.53 & 0 & 1 & 50.71 \\
\hline
\end{tabular}




\begin{tabular}{|c|c|c|c|c|c|c|}
\hline $\begin{array}{l}\text { fbreeding success }=\text { intercept }+ \text { insect abundance }+ \text { conspecific density } \\
+ \text { squirrel presence/absence }+ \text { territory size }+ \text { percent shrub cover }+ \\
\text { proportion trees conifer }+ \text { site context }\end{array}$ & & & & & & \\
\hline $\begin{array}{l}\text { insect abundance }=\text { intercept }+ \text { site context }+ \text { year } \\
\text { conspecific density }=\text { intercept } \\
\text { łsquirrel presence/absence }=\text { intercept } \\
\text { łproportion trees conifer }=\text { intercept } \\
\text { łpercent shrub cover }=\text { intercept } \\
\text { łterritory size }=\text { intercept }+ \text { conspecific density }+ \text { percent shrub cover }+ \\
\text { site context } \\
\text { łbreeding success }=\text { intercept }+ \text { insect abundance }+ \text { conspecific density } \\
+ \text { squirrel presence/absence }+ \text { territory size }+ \text { percent shrub cover }+ \\
\text { proportion trees conifer }+ \text { site context }\end{array}$ & 24 & 99.10 & 21.93 & 0 & 1 & 51.10 \\
\hline
\end{tabular}

